Article

\title{
Framing Processes in the Envisioning of Low-Carbon, Resilient Cities: Results from Two Visioning Exercises
}

\section{Stephen McGrail ${ }^{1, *}$, A. Idil Gaziulusoy ${ }^{2}$ and Paul Twomey ${ }^{3}$}

1 Swinburne Institute for Social Research, Swinburne University, Hawthorn VIC 3122, Australia

2 Victorian Eco-Innovation Lab (VEIL), Faculty of Architecture, Building and Environment, University of Melbourne, Parkville VIC 3010, Australia; E-Mail: idil.gaziulusoy@unimelb.edu.au

3 Faculty of Built Environment and Centre for Energy and Environmental Markets, University of New South Wales, Sydney NSW 2052, Australia; E-Mail: p.twomey@unsw.edu.au

* Author to whom correspondence should be addressed; E-Mail: smcgrail@swin.edu.au or stephen.mcgrail@gmail.com; Tel.: +61-0-419-533-712.

Academic Editors: Tan Yigitcanlar and Md. Kamruzzaman

Received: 10 May 2015 / Accepted: 24 June 2015 / Published: 3 July 2015

\begin{abstract}
Visioning exercises were convened in Melbourne and Sydney, Australia, to explore how these cities could become low-carbon and maintain resilience over the next 25 years. Drawing on the concept of frames-in particular Schon and Rein's conceptualisation of a frame as a "diagnostic-prescriptive story" that is based on an underlying structure of beliefs, perceptions and appreciation-this paper seeks to: Attend to the ways that workshop participants framed the problems (of emissions reduction and maintaining resilience); surface framing processes and potential related sources of political contention; and discuss the role of visioning exercises in sustainability transitions. Five frames are identified, along with the interpretive orientations underpinning each frame, framing processes and the potential for frame conflict and alignment. The study suggests that the designers and facilitators of visioning exercises need to be attentive to framing processes, potential framing contests, and related social processes during a visioning exercise. Key implications are identified, with a focus on whether an exercise seeks to "open up" a complex issue or to agree upon a singular, i.e., consensual, agenda.
\end{abstract}

Keywords: frames; framing processes; low carbon cities; visioning; urban resilience 


\section{Introduction}

Over the past decade or so, anticipatory knowledge and visions of the future have been the focus of increasing social scientific research. For example, scholars have considered these in the context of the state such as their use to generate support for policy initiatives, in science and technology policy, and in relation to socio-technical change processes (e.g., [1-4]). In particular researchers in the field of Science and Technology Studies (STS) have paid increasing attention to how knowledge claims about the future are produced and mobilised for a range of purposes (e.g., [5,6]). This research has revealed the diverse roles played by expectations such as the role of technological expectations and expectations about market potential in investment decisions, and the role of normative expectations in coalition-formation. It has also demonstrated that how such knowledge is made and used matters.

Participatory “foresight” exercises are one such activity where future expectations are elicited and, to some extent, shaped through discussion and analysis [7]. This paper reports on forward-looking workshops that were run as part of an Australian project called Visions and Pathways 2040 (hereafter, VP2040). Through research and engagement activities the VP2040 project is examining visions, scenarios, and pathways for low-carbon resilient futures in Australian cities. The VP2040 project is one of an increasing number which view cities as a significant intervention point for climate change action and views the social challenge of rapidly reducing emissions and generating resilience in urban contexts as primarily a system innovation challenge. The project is funded by the Cooperative Research Centre (CRC) for Low Carbon Living, a multi-university and cross-sectoral research initiative established in 2012 to advance low-carbon innovation and urban transitions.

The first phase of the VP2040 project sought to elicit existing actors' expectations about the future focussed on what a desirable, low-carbon, resilient future for major Australian cities could look like. This was primarily accomplished through engagement exercises (which are outlined in more detail in below), in which participants shared ideas and were encouraged to imagine "business-as-unusual" futures. Designers and architects were also engaged to help with visualising these concepts. This paper describes, and presents an analysis of, the key outputs of this phase and other data gathered via a pre-workshop survey. The primary aims of this paper are to: (1) describe the different perspectives on a desirable, low-carbon, resilient future that were articulated (primarily focussed on major Australian cities); (2) identify the related problem framings and understandings that shaped these perspectives; (3) assess whether, and in what ways, framing processes may have influenced these exercises; and (4) consider the implications of these diverse framings and framing processes, such as regarding the potential for frame conflict or supportive alignments. Drawing on this analysis, we also discuss the role of visioning-style exercises and framing processes in sustainability transitions.

A related central argument is developed. We argue that the results of the study show that in participatory visioning exercises diverse institutionally-related and culturally-grounded framings of the complex social issues are voiced which are informed and shaped by contextual assumptions and already circulating understandings (e.g., about urban planning and city futures). These framings influence consideration of alternative solutions. Proponents of alternative framings often compete to influence the resulting visions through a complex social process that can be termed "framing contests" [8]. Surprisingly, this is also true for the relatively homogenous groups which participated in these workshops. From a practitioner perspective the paper concludes that the organisers and facilitators of 
visioning exercises need to be more attentive to framing contests and related social processes, along with whether the exercise seeks to open up debate or to achieve closure on a consensual agenda.

\section{Introduction to the Visioning Exercises}

In the first half of 2014, visioning exercises were held in Melbourne and Sydney, the two largest cities in Australia. A diverse mix of participants from government, business, academic, and the broader community attended-103 in total (see Table 1 below), 66 in Melbourne, 37 in Sydney—who shared a concern about climate change and related sustainability issues and interest in the future of cities. The attendees were the result of an invitation process based on an active search for relevant experts (e.g., web research, review of conference presenters to identify suitable experts) and the existing professional networks of project staff. One consequence of this approach is that most participants also had a strong knowledge of, and/or relevant interest in, the built environment along with related areas of public policy and innovation. Other consequences of this approach are possible, such as via sampling effects, and these are considered in the analysis and discussion sections.

Table 1. Breakdown of sectoral representation in the workshops.

\begin{tabular}{lc}
\hline \multicolumn{1}{c}{ Sector } & $\begin{array}{c}\text { Number of } \\
\text { Participants }\end{array}$ \\
\hline Business sector (built environment sector: e.g., urban design firm, & 27 \\
engineering/construction; renewable energy/clean energy, etc.) & 22 \\
Research (university-based researcher; and non-university based researcher) & 15 \\
Local Government & 11 \\
NGO (e.g., WWF Australia) & 10 \\
State Government & 6 \\
Peak bodies (e.g., the Green Building Council of Australia) & 4 \\
Media/creative arts & 3 \\
Utilities & 3 \\
Social enterprises & 2 \\
Financial bodies/institutions & 3 \\
\hline
\end{tabular}

Participants were asked to complete a pre-workshop survey (please refer to the Supplementary Information for full details) that sought to both prompt some future-oriented thinking and help the organisers to better understand participants' expectations for, and interest in, the workshops. A total of 43 participants from the Melbourne workshop completed the survey (response rate of 65\%); 22 participants in the Sydney workshop completed the survey (59\%).

A two-stage workshop process was then conducted and used the following procedure:

- An initial half-day workshop was conducted in which participants shared and discussed their long-term visions for a low-carbon, highly resilient Melbourne or Sydney (depending on the workshop) in the year 2040. In small groups they moved through five themed discussion tables — shelter, energy, transport, food and water, and lifestyle and behavior — with the intention of gradually enabling a more holistic view of urban life and related systems. This workshop was 
also attended by designers who played central roles in the next two steps. The designers were asked to treat the workshop dialogue and workshop outputs as a design brief;

- The designers were then tasked with developing rough visualisations of the future(s) that were discussed in the initial workshop. These visualisations were termed glimpses as they are partial snapshots of possible futures (not a blueprint or a complete vision); and

- A second focus group style workshop was then held in which the designers presented the rough visualisations, followed by table-based small group dialogue on the glimpses. Participants responded to the glimpses, such as commenting on their desirability and plausibility.

Participants were also instructed to consider two core normative targets. The future city had to achieve a significant reduction in greenhouse gas emissions, specifically an 80\% reduction by 2040 on 2014 levels (which is consistent with recommendations made by the Climate Change Authority, the relevant statutory authority in Australia). Secondly, the imagined future city must also be one that is resilient such as with respect to the future challenges of climate change (e.g., adjusting to new climate patterns) and having the ability to cope with related environmental shocks.

The analysis presented in Section 4 reports on the pre-workshop survey which was completed by the majority of participants, visioning workshop dialogue and associated process outputs.

\section{Conceptual Framework and Theoretical Background}

Concepts like low carbon living and urban resilience, and successful forms of adaptation to climate change, have different meanings for different people. Moreover, in important ways these meanings and associated judgements (e.g., regarding the question of climate adaptation "success" or "failure") are historically contingent and context-specific [9]. Whilst aspects can be determined or measured in a traditional scientific manner, many aspects are subjective and/or normative.

As Snow et al. [10] outline, the concept of a frame refers to the schemata of interpretation that are used when individuals perceive, identify, and label events (or “occurrences”) in their life and in the world at large. This conceptualisation draws on Erving Goffman's original theorisation of frames (e.g., see his book Frame Analysis). Benford and Snow [11] further define a frame as "constituting a broader, interpretive answer or definition to 'what is going on' or 'should be going on'”, emphasising the interpretive dimensions. Related framing processes can produce collective action frames which are more than an individual construct; they are shared action-oriented sets of beliefs and meanings, involving the negotiation of shared meanings. In all these ways frames and framing processes are about reality construction and the production and maintenance of associated meanings [11].

In their influential book Frame Reflection Schon and Rein [12] make a broader related argument about how actors engage with problematic complex situations such as the challenge of decarbonising a city or an economy. They argue that actors must cognitively process situations that are ambiguous, indeterminate, and/or vague in ways that make them more intelligible. Through a process termed "naming and framing" they argue that actors construct selective stories: "From a problematic situation that is vague, ambiguous and indeterminate, each story selects and names different features and relations that become the "things" of the story-what the story is about. Each story places the features it has selected within the frame of a particular context” [12]. Actors select out the features and relations seen 
as relevant and important. According to this perspective, complex problem situations can be framed in multiple, sometimes incompatible, ways and there is no "correct" description.

Schon and Rein further argue that frames have normative implications and execute a "normative leap”. That is, frames should be understood as "diagnostic-prescriptive stories”. For example, this is seen in the construction of policy frames and "generative metaphors that underlie them" [12].

Recently the concept of a frame has gained currency in many social sciences and it has especially been used to help to underscore the culturally constructed dimensions of social action $[11,13]$. For instance, social movement scholars argue that collective action frames are constructed and used by movement actors, and others, to simplify and condense aspects of the social world in strategic ways. An example is the way issues get defined in ways that are intended to mobilise adherents, garner bystander support, and demonise antagonists. By resonating with varying groups and being open to interpretation and modification, frames can help to enable collective action [13]. Framing processes can also generate or draw on cultural understandings that offer actors motivating identities.

Some sustainability-focussed scholars also emphasise framing. In Dynamic Sustainabilities Leach et al. [14] emphasise the framing processes which they argue shape the analysis of complex systems and influence how complex sustainability problems are analysed and understood. For them, framing refers to "the particular contextual assumptions, methods, forms of interpretation and values that different groups bring to a problem, shaping how it is bounded and understood”. Such processes involve selective perception (i.e., choices about what elements to pay attention to and emphasise), and subjective value judgements, and are also shaped by the contexts in which people think and act; as summarised in Table 2 below. Leach et al. [14] further argue that "framings are produced by particular actors and co-constituted with their particular institutional, political and life settings”. Drawing on a social constructivist epistemological perspective, they further argue that diverse understandings of sustainability problems are inevitable and call for approaches that aim to enhance reflexivity.

Table 2. Key dimensions of framing [14].

\begin{tabular}{ll}
\hline Choice of Elements & Subjective Judgements \\
\hline - Scale & - Interests \\
- Boundaries & - Values \\
- Key elements and relationships & - Goals \\
- Dynamics in play & - Perspectives \\
- Outputs & - Notions of relevant experience \\
\hline
\end{tabular}

A number of related arguments are made. Firstly, that greater attention needs to be given to the multiple, diverse framing of complex sustainability issues in order to open up related debates and policy-making processes. Secondly, framings — such as problem framings, or system framings—often become part of larger cultural narratives that are constructed about a problem, its causes, and the solutions that are seen as required to bring about a set of preferred/desired outcomes [14].

Finally, Vogel [15] has developed the related concept of anticipatory frames. For example, Vogel [16] demonstrated the existence of competing framings of biotechnology in assessments of biosecurity threats and related policies. In Vogel's analysis, anticipatory frames have three main elements: Core assumptions (e.g., made about the future); particular pieces of information that are 
privileged or fixated on; and frames are related to practices (e.g., organisational practices). In the case of frames about emerging technologies (e.g., biotechnology) a frame also incorporates actors' beliefs about technological trajectories, temporal and spatial orientations, and specific foci of attention [16].

In the analysis that follows here, a similar approach to Vogel's analysis will be used to explicate the frames of low-carbon, resilient cities that were expressed by workshop participants. In addition, following Schon and Rein's conceptualisation, we consider a frame to be a diagnostic-prescriptive story which is based on underlying structures of beliefs, perceptions, and selective appreciation.

\section{Framing Processes, Low-Carbon Transitions and Broader Sustainability Transitions}

Some transition theorists such as Geels have considered the role of framing and related cultural understandings and factors in transition processes. Geels has considered two different aspects. First, building on Snow and Bedford's work (which was cited earlier) he argues that framing strategies are used by incumbent actors to try to avoid or forestall threatening changes [17]. As an example of problem reframing, he argues incumbents in existing energy industries and regimes benefitted from the redefining of energy policy problems to also include maintaining energy security and energy affordability (i.e., not only reducing of greenhouse gas emissions). For example, “coal was increasingly (re)positioned as an answer to energy security and affordability" [17]. Second, other forms of framing include motivational and prognostic framing. Some historical cases of regime destabilisation and major transitions indicate that cultural understandings and frames can play roles in achieving such transitions. Drawing on the history of the British coal industry, Turnheim and Geels [18] argue that "public support for purposive transitions depends not only on a perceived urgency of problems" but also requires a broader "cultural package" which, in the case they examined, included "new visions of modern, clean, convenient, smokeless households". In other words, diagnostic and prognostic framings can contribute to public support for policy change and associated transitions.

Additionally, it is important to note that, in the sustainability transitions field, transitions towards sustainability are typically "framed from a systems perspective" [19]. That is, changes are seen as being required and as unfolding at the broader system-level, such as for entire mobility systems or energy systems. System changes are envisaged to occur through interconnected technological, organisational, and social and institutional changes, often termed socio-technical transitions.

\section{Materials and Methods}

Three key sets of data were collected during the visioning process and reviewed for this study: (1) pre-workshop survey responses ( $n=65)$; (2) notes from the table-based dialogue that occurred during the visioning workshops (the authors were also co-facilitators of these workshops); and (3) the visualisations that we produced based on the dialogue at the workshops, which are referred to below as glimpses. The visioning exercises (described in Section 1) and survey (see Supplementary Information) provided opportunities for participants to articulate their views on preferred urban and low-carbon futures, including views on their subjective preferences in relation to these futures and their diagnosis of problems that need to be addressed in order to move towards such a preferred future. Consequently, these statements provide rich sources of data that can be reviewed in order to consider what frames were articulated and drawn on and related framing processes. 
Responses to the following three pre-workshop survey questions were focussed on:

- What have been the main forces and processes of change that have shaped [specific city] life over the past 30 years? [Specific city = Melbourne or Sydney]

- Imagine you are living in [specific city] in 2040. It is now a global model city of a super-low-carbon city that can bounce back from extreme weather events and other shocks. You receive a visit from friends (via a time machine) from the year 2014. What are the first things you would want to show these time tourists that would "prove" that an extraordinary 26 years have passed?

- What “disruptive” forces do you think will affect [specific city's] pathway to a low carbon city over the next 30 years?

Survey respondents were also asked to provide details on their profession and work (e.g., the organisation they work for). This allowed for high-level consideration of the institutional settings of those articulating frames, e.g., whether there were such patterns as predicted by framing theory.

By review we mean that an informed assessment of the data was conducted which considered relevant framing theory. For example, we asked: Did participants focus on different scales (e.g., focus on local-level decarbonisation activities and localised resilience at the suburb/precinct scale or, alternatively, adopt a multi-scale perspective on decarbonisation and resilience)? Did participants tend to "bound" the problems in unique ways (e.g., primarily considering greenhouse gas emissions produced within the city such as from transportation or, alternatively, adopting a broader problem boundary such as also considering the greenhouse gas emissions that are embedded in the consumption choices of city residents)? How did participants think such problems ought to be addressed-was there wide agreement or distinct preferences/positions? This analysis progressed through three main stages: (1) the survey responses were initially reviewed to identify statements and beliefs indicative of potential frames and related elements (e.g., institutional settings); (2) the visualisations (workshop outputs) were reviewed to further "capture" each frame and consider their consistency with each frame (that is, was the prognostic aspect of the frames consistent with outputs?); (3) the uniqueness of each identified frame was systematically considered as per frame theory and framing elements discussed above. Following the visioning workshops the project team also critically discussed the perspectives that were voiced at the workshop, considering the main areas of divergence/convergence and any related conflicts. These team discussions provided a further way to review, clarify and assess the frame analysis.

Informed by the literature review, six major dimensions were considered when defining and comparing each frame, allowing for a more systematic analysis of each frame:

- Diagnostic framing: e.g., diagnosis of the focal problem(s); main aspects emphasised;

- Choice of elements: e.g., focal scale/spatial orientation (e.g., suburb, city-scale), boundaries, etc.;

- Assumptions: e.g., assumptions about technological options and trajectories;

- Primary actors;

- Subjective judgements: e.g., more or less important social/policy goals and outcomes; and

- Institutional settings (i.e., of those who articulated the frame).

Five different, and partially competing, frames were identified, and associated framing processes (that influenced these frames) were examined. These frames and framing processes are described in the next section, and are subsequently critically discussed in Sections 4.8 and 5. 


\section{Results and Discussion}

\subsection{Frame 1: Localised Urban Sustainability; Re-imagining the Suburb, Neighbourhood and Home}

Many participants focussed on envisioned changes at the suburb and/or precinct scale. The focus is on new types of suburbs, neighbourhoods, and homes within them, which are significantly more self-sufficient or self-contained, especially with respect to energy, water, and food. One participant termed such future suburbs "micro cities". Keywords for this frame include local, decentralised, and distributed (e.g., distributed local energy production systems). Urban agriculture is also embraced. Use of distributed and decentralised energy generation-especially via renewable and other lower-emissions technologies, combined with new energy storage technologies-is envisaged to be the best way to reduced greenhouse gas emission. Resilience is interpreted as requiring greater self-reliance and self-sufficiency, with some participants viewing existing long supply chains and associated infrastructure as a source of vulnerability and arguing that "re-localisation" is necessary for maintaining resilience. These changes are combined with other priority social goals such as community development, and re-balancing private and public space (see Figures 1 and 2).

Participants expressing this framing of low-carbon, highly-resilient cities stated that they would show time travellers (who visited this future city in 2040) the following key features:

"Self-sufficient and interconnected suburbs and precincts-with regard to:

- energy consumption and production

- fresh food production

- a different structure to the common working week so that if one is able and chooses, one can manage one's life re: food production or producing wares or developing oneself personally or giving time to things that are important like family and children. [Sector: Peak body (green building sector); Workshop location: Melbourne]

"Transformation of suburbs to double or triple (or more) the local housing yields and populations. Tangible focus on local neighbourhoods as self-sustaining, with local jobs, clear local centres and production loops” [Sector: Business—urban design/urban planning; Workshop location: Melbourne]

"I'd take them out to the parts of Melbourne that were formerly car dominated, homogenously residential, consumption based suburbs, to observe a distinctly urban phenomena: People of all ages and gender cycling; local employment, services and production; complete utilisation of urban water resources; urban forests and food production. And the crowning glory — "living buildings" that are internally homeostatic, run on sunlight and take carbon out of the atmosphere." [Sector: Local Government; Workshop location: Melbourne]

"The urban villages where people live, work, create and grow without needing to travel far... [the] solar panels coating surface after surface. The roads that have been handed over to pedestrians" [Sector: Research; Workshop location: Sydney] 
"[I'd show the "time traveler" that] suburbs are micro cities [and] they are self-contained" [Sector: Business; Workshop location: Melbourne]

"The elimination of the car and the rise of urban agriculture in the spaces the car left behind." [Sector: Business—urban design/urban planning; Workshop location: Sydney]

In some cases this frame also included reference to development of "polycentric” cities, e.g.,

"There are six other business districts (hubs) in the Melbourne metro area other than the CBD” [Sector: Social enterprise; Workshop location: Melbourne]

"[I'd show the "time traveler"] the green building and tree-lined avenue of Parramatta Rd, the shady, water features of Penrith and Liverpool CBDs, the agricultural businesses thriving in Sydney's green spaces and on its fringe." [Sector: Business-built environment/professional services; Workshop location: Sydney]

Others envisioned related changes such as: Development of "new, dense, diverse urban places" [Sector: urban design; workshop location: Sydney] and "rectification of urban sprawl” [Sector: urban design; workshop location: Melbourne], and a future in which "nearly everything, that is practicable, is local: Food, energy, water, jobs, education, etc.” [Sector: Local government; workshop location: Melbourne]. Another participant from local government stated that: "We'd visit a once sprawling outer suburban area where (at great expense) public transport had been added and a dense walkable and vibrant hub had been created” [Sector: local government; workshop location: Melbourne].

This framing also informs some of the visualisations that were developed. Some of the glimpses portray a future city with more communal land (such as the glimpses shown in Figures 1 and 2 below) and urban "villages” that support more localised living (see Figure 3).

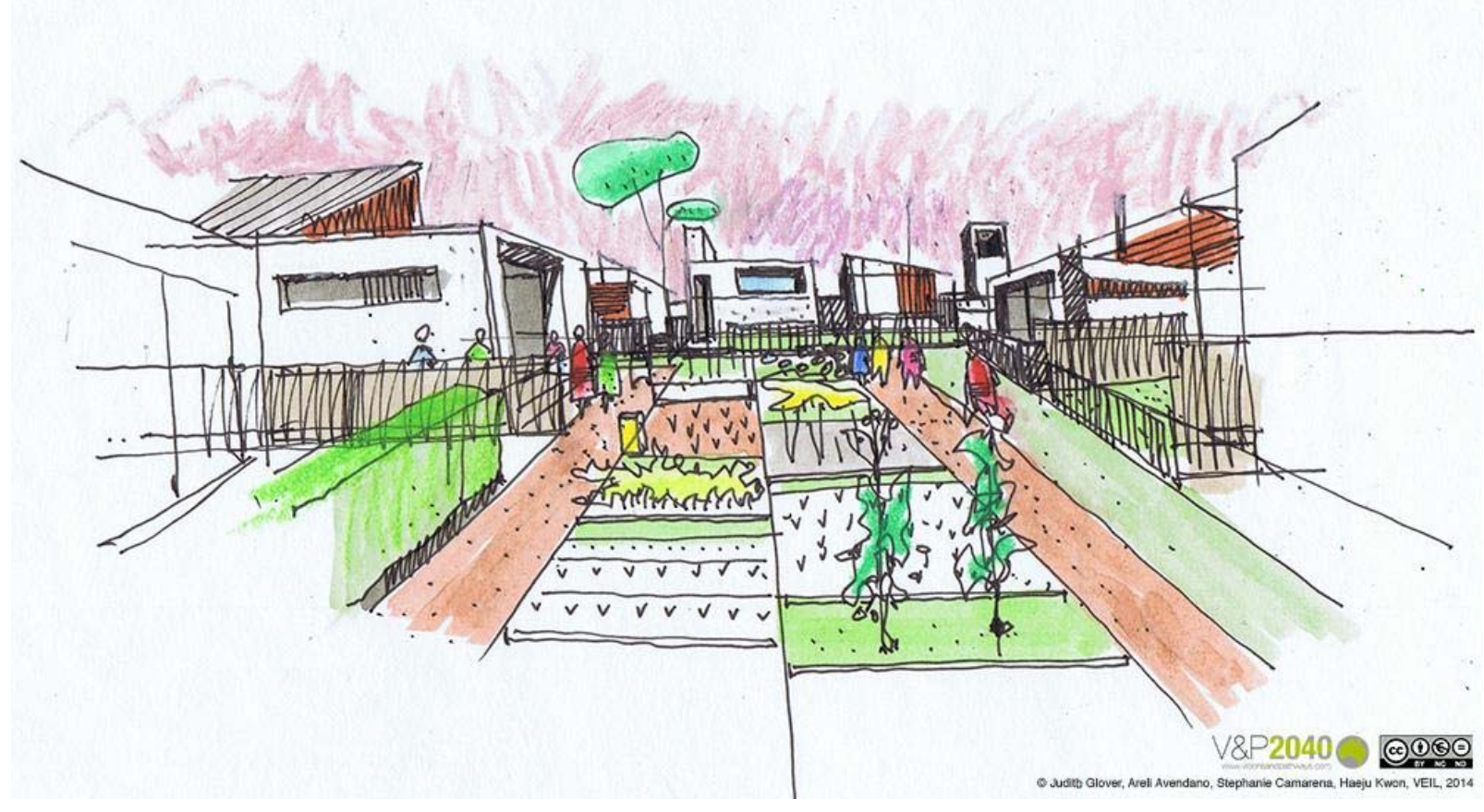

Figure 1. Less emphasis on owning a private backyard: Residents work together to maintain communal and/or shared land (that was formerly private backyards) such as for food production. 


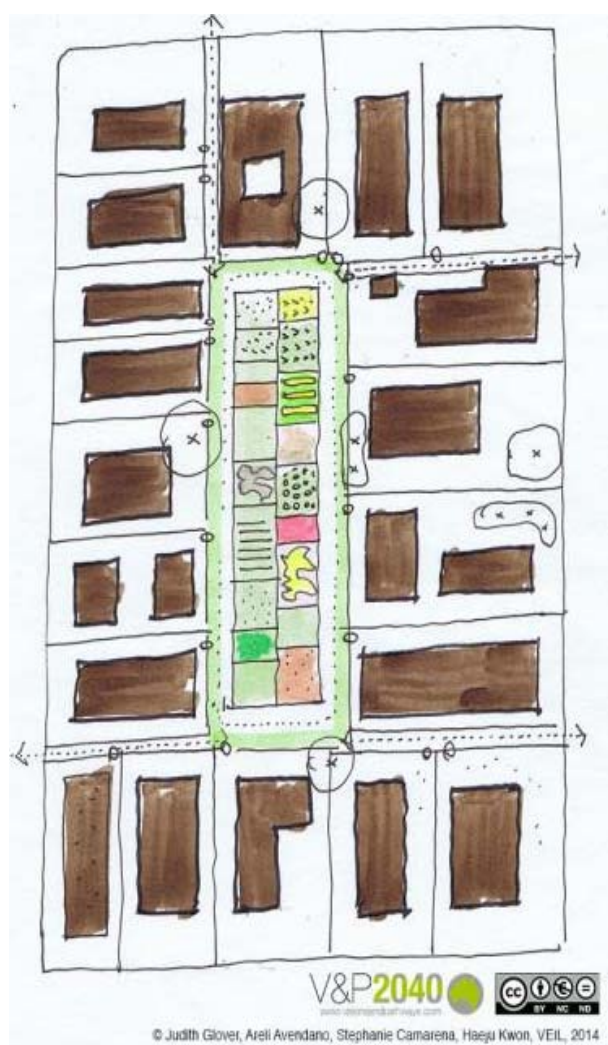

Figure 2. Growth of communal spaces in new housing estates and urban precincts.

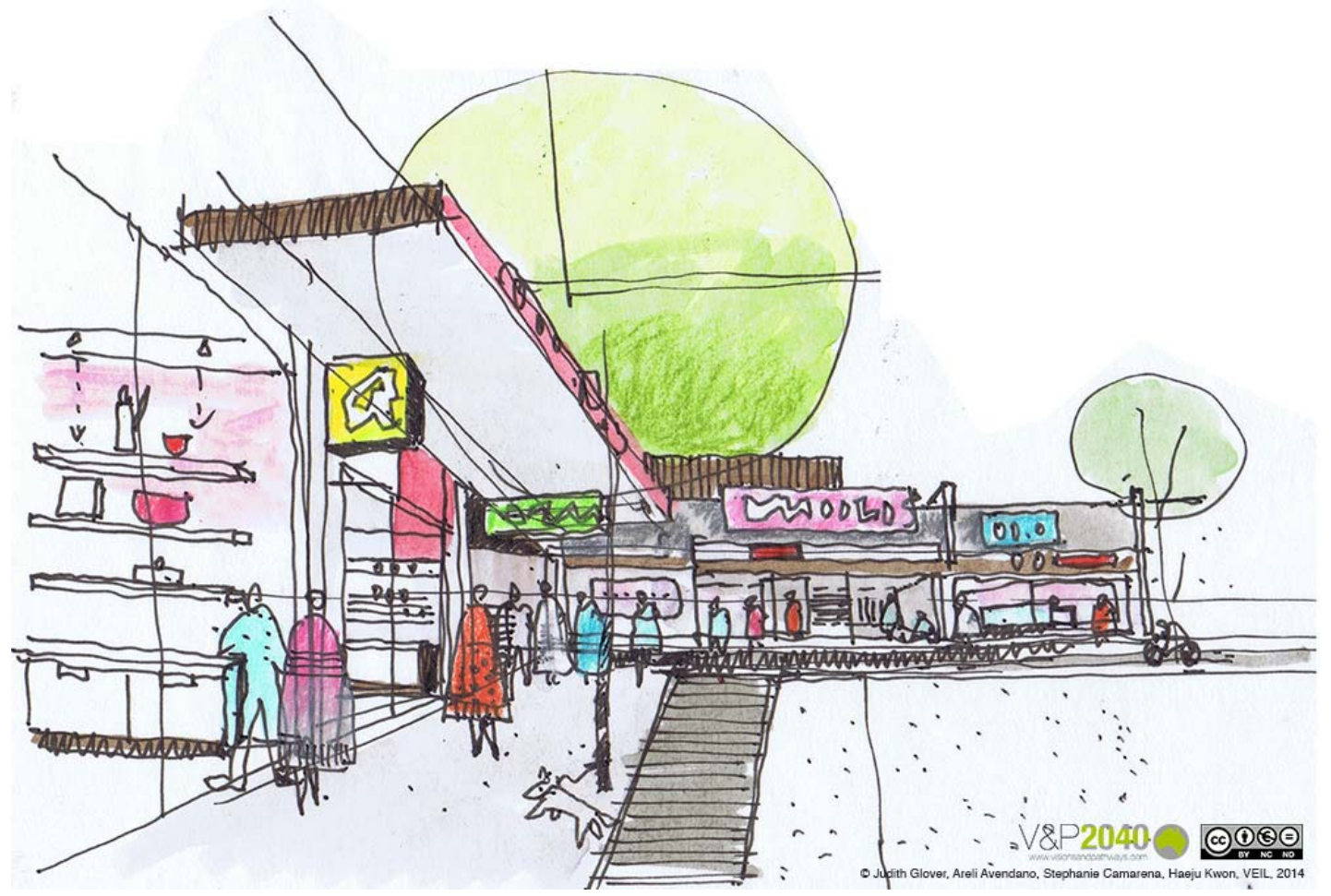

Figure 3. Local shopping and produce: a mosaic of urban "villages" now exists including localised hospitals, employment, schools, and self-contained water and food production. Supermarkets do not disappear but incorporate local produce. Technology improves the flow of information and introduces new models of communication, e.g., an app informing residents which trees are currently fruiting. 
Additional glimpses conveyed the concept of local community "hubs". The concept of new flexible civic/educational/commercial community spaces is shown in Figure 4 below.

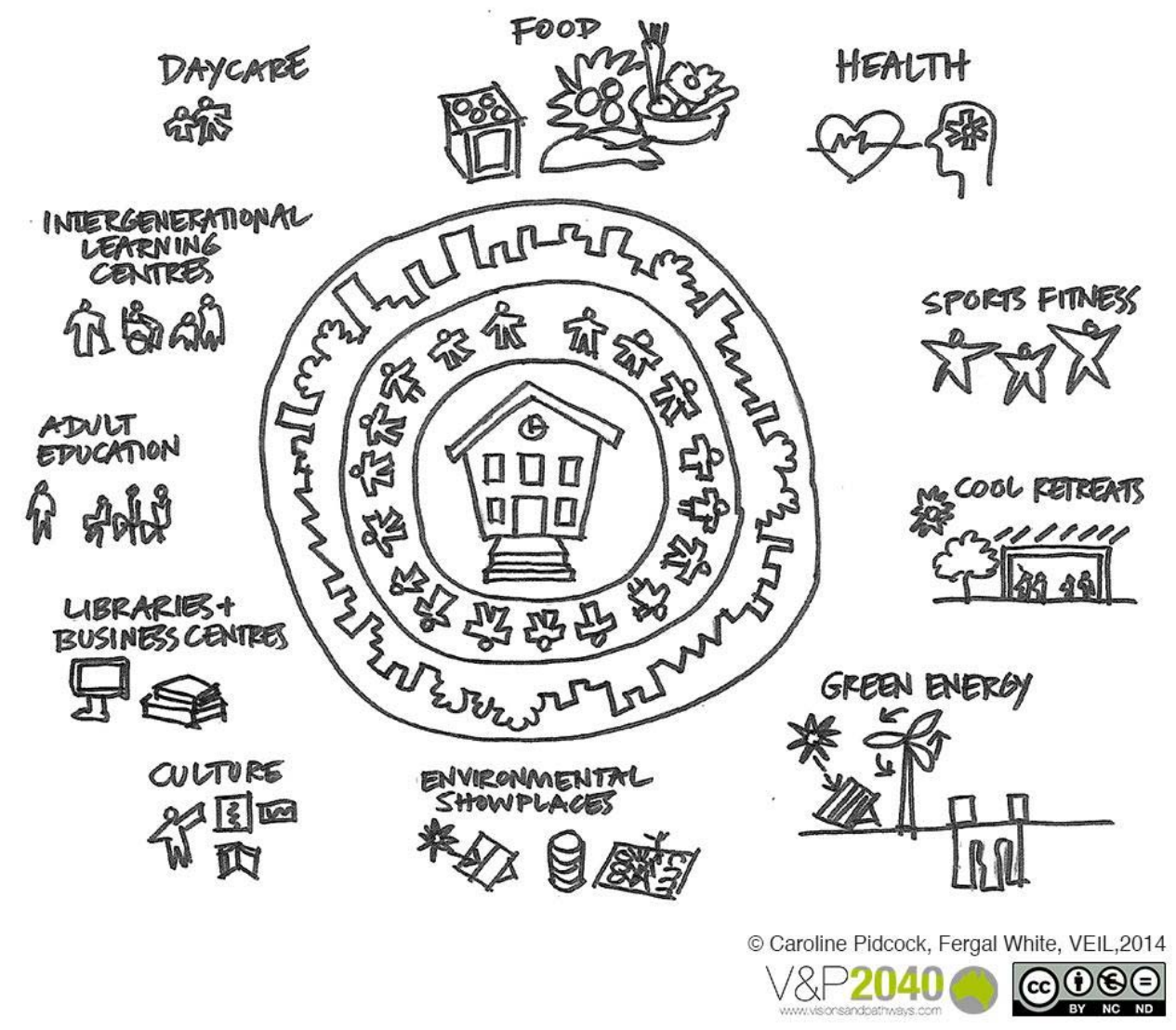

Figure 4. Local "hubs": flexible community spaces that support and empower local people and businesses, and can also serve as "cool retreats" during major heat events.

Major elements of this frame are summarised in Table 3 below.

Table 3. Summary of the "localised urban sustainability" frame.

\begin{tabular}{|c|c|}
\hline Element & Details (in Brief) \\
\hline Diagnostic framing & $\begin{array}{l}\text { - Poor government/urban planning and related market-driven urban } \\
\text { change “locking-in” consumption and high emissions-intensity } \\
\text { - Car-dependence related to poor planning and continued urban sprawl } \\
\text { - } \quad \text { "Introverted”, individualistic urban living (cultural problems) }\end{array}$ \\
\hline Elements emphasised & $\begin{array}{l}\text { - Local-level changes: Suburbs, precinct planning, dwelling types } \\
\text { - Urban density } \\
\text { - Threats to the resilience of urban communities/environments } \\
\text { - Factoring in broader resilience issues into urban planning (e.g., resilient } \\
\text { food systems, water supply/systems, natural resource limits) }\end{array}$ \\
\hline Assumptions & $\begin{array}{l}\text { - A high degree of localised self-sufficiency is a realistic possibility } \\
\text { - Long supply chains and associated existing infrastructures (e.g., food and } \\
\text { energy supplies) make urban communities vulnerable } \\
\text { - Limited trade-offs exists between increased urban density and other } \\
\text { social, environmental and other policy objectives }\end{array}$ \\
\hline
\end{tabular}


Table 3. Cont.

\begin{tabular}{|c|c|}
\hline Element & Details (in Brief) \\
\hline Primary actors & $\begin{array}{l}\text { - Local citizens and local governments } \\
\text { - Urban designers and planners }\end{array}$ \\
\hline $\begin{array}{c}\text { Subjective } \\
\text { judgements }\end{array}$ & $\begin{array}{l}\text { - Preference for localisation and local non-commercial ownership } \\
\text { - Related goals of greater decentralisation and local "connectedness" }\end{array}$ \\
\hline $\begin{array}{l}\text { Institutional settings } \\
\text { (main themes) }\end{array}$ & $\begin{array}{l}\text { - } \text { Local government } \\
\text { - Urban design firms, architecture/design professionals; related peak } \\
\text { bodies (e.g., Green Building Council of Australia) } \\
\text { - University-based research organisation }\end{array}$ \\
\hline
\end{tabular}

\subsection{Frame 2: Radical Shifts in Political Economy and Material Consumption}

Some workshop participants emphasised much more radical shifts in socio-economic organisation and associated ways of life and patterns in economic activity when asked what they would show a time traveller from 2014. Similarly, some of the glimpses shown below were framed by shifts towards greater sharing behaviours and were characterised as being "slow" and "less products, more experiences”, about communalisation and changes in values.

According to this issue framing, low carbon living and associated transformations towards a low carbon economy and resilient communities must focus on reducing material consumption, and associated changes in values and economic activity. Additional aspects that are emphasised by this framing-and not the others described in this paper-are the indirect greenhouse gas emissions generated by production processes located elsewhere and by freight/logistics. Consumer culture is critiqued, along with dominant status symbols (e.g., a large home, privately-owned vehicles, other accumulated belongings, etc.), and the pursuit of affluence. Simpler living is promoted.

Additionally, participants expressing this framing of low-carbon, highly-resilient cities stated that they would show time travellers (who visited this future city) the following key features:

"I would want to show them a city where public transport and bike travel eclipses car use. I would want to show them a city with no bottled water, no takeaway food, no smoking, fit and healthy people, community groups actively practicing yoga and meditative practices, I would like to show them large tracts of land and parks filled with edible gardens tended. I would like to show them new education and learning models that are collaborative and non-competitive." [Sector: Social enterprise; Workshop location: Melbourne]

"We have sophisticated social and economic systems for measuring externalities like carbon, health, wellbeing, and happiness. We have a post-growth, steady-state economy. Nurturing, protecting and valuing the Commons is the key priority for business, government and society. People define wealth through their social relationships. Large amounts of food is grown locally in community gardens. There are no cars in the city. Energy is produced locally through distributed grids using renewable energy. People only work for money by choice and not more than 3 days per week." [Sector: Social enterprise; Workshop location: Melbourne] "[I'd show the "time traveler"] documents from a variety of flourishing sharing economy initiatives I'm part of: A cooperatively owned electric car sharing club, my food cooperative 
that makes regular farm visits, and photos of the community energy scheme I've invested in.” [Sector: Research (university-based); Workshop location: Sydney]

"The whole place will have (for the 2014 visitor) a strong "whiff" of what he or she would describe, perhaps based on earlier travels to less-developed countries, as poverty, but which seems unremarkable to the 2040 citizens-e.g., obvious repairs to clothing; old objects and tools well maintained; breakdowns encountered with good humour. Obvious use of (and reliance on) "legacy technologies". Lots of people engaged in maintenance activity. People obviously taking the time to help each other with day-to-day tasks. A subtle sense of reduced busy-ness-simultaneously with a lot of engagement in hard physical work." [Sector: Research (non-university based); Workshop: Melbourne]

"[I'd show the "time traveler" the] massive social change that has taken place to enable these things, people are more aware of their place in the ecological balance and values are different. Combined with this, new forms of democracy that involve the community in INFORMED decision making (possibly inspired by Swiss direct democracy model)" [Sector: Research (university-based sustainability institute); Workshop location: Sydney]

"[I'd show the "time traveler"] the lack of cars, what people do with their extra free time" [Sector: Research (university-based); Workshop: Melbourne]

Similarly, another respondent would show a visitor from 2014 the "palpable culture of sharing”, "culture and governance of making decisions bottom-up", and "hyper local pockets of diverse, interdependent economies and social neighbourhoods” among other key changes [Sector: Business-architecture practice; Workshop location: Melbourne].

One way that some aspects of this frame can be further described is as a critique of urbanism as a way of life (i.e., urban modes of social life). For example, in his sociological theorisation of urbanism Wirth [20] argued that urban life in large cities has fundamentally altered the nature of social relationships, such as generating a tendency for weaker social bonds. He further termed this "the superficiality, the anonymity and the transitory character of urban-social relations”. He further pointed to a loss of "the sense of participation that comes from living in an integrated society". The pace of life in urban contexts is generally much faster than rural areas, along with more insecure. Critiques of urban ways of life are, in this frame, linked to the low-carbon and resilience agendas. Or, put another way, the low carbon cities debate provides a new space in which these issues are given voice.

Another survey question asked participants to nominate positive and negative "disruptive" forces what will shape the city's "pathway to a low carbon city over the next 30 years". Noting responses by the participants whose interpretations fully, or in part, express this frame helps to further explicate this perspective. Disruptive forces that were listed as negative include: Aggressive pursuit of "affluence entitlement”; narcissism; and patents. Disruptive forces listed as positive included: Voluntary simplicity; sharing and sharing economy initiatives; collaboration; peer production; participatory democracy; peak oil; and tangible ecological collapse and climate change.

This framing also informs some of the visualisations that were developed. Some of the glimpses portray a future in which there is less emphasis on ownership, such as ownership of private vehicles (see Figure 5), and shopping centres are transformed due to reduced consumerism (Figure 6). 


\section{Repurpose the surface}

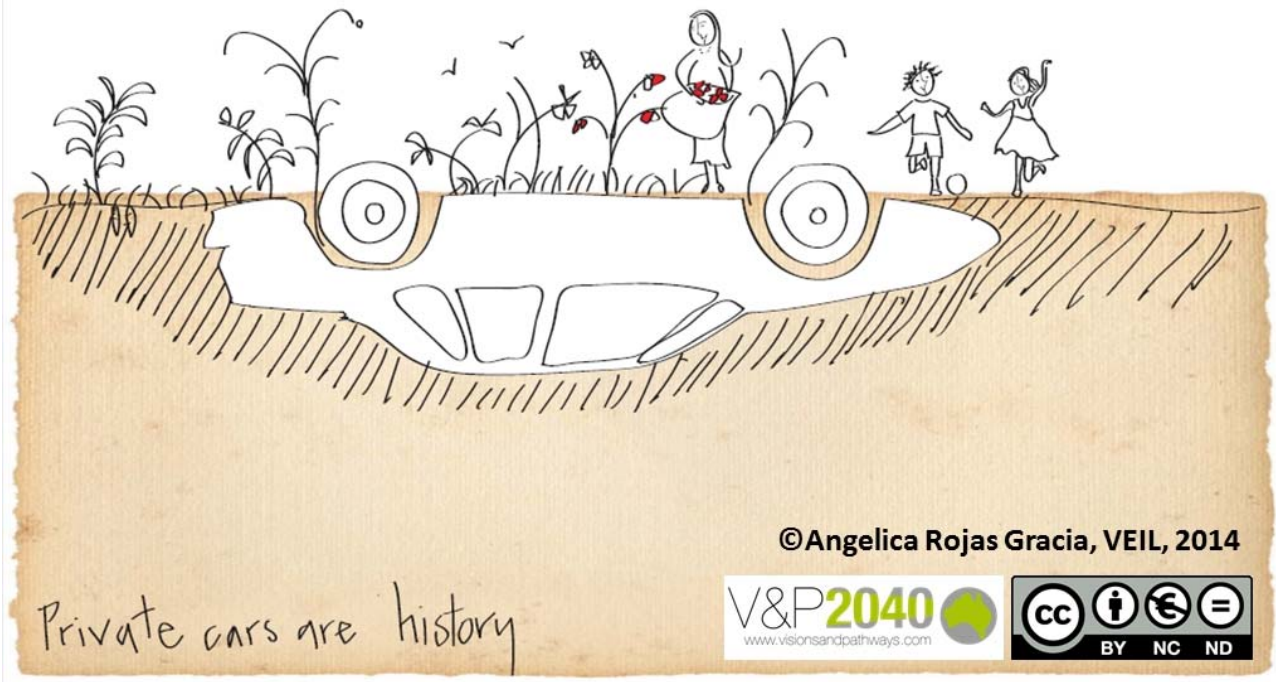

Figure 5. Deprivatisation of personal transport and repurposing of land and buildings previously dedicated to private vehicles (e.g., car parks, fewer roads, etc.).

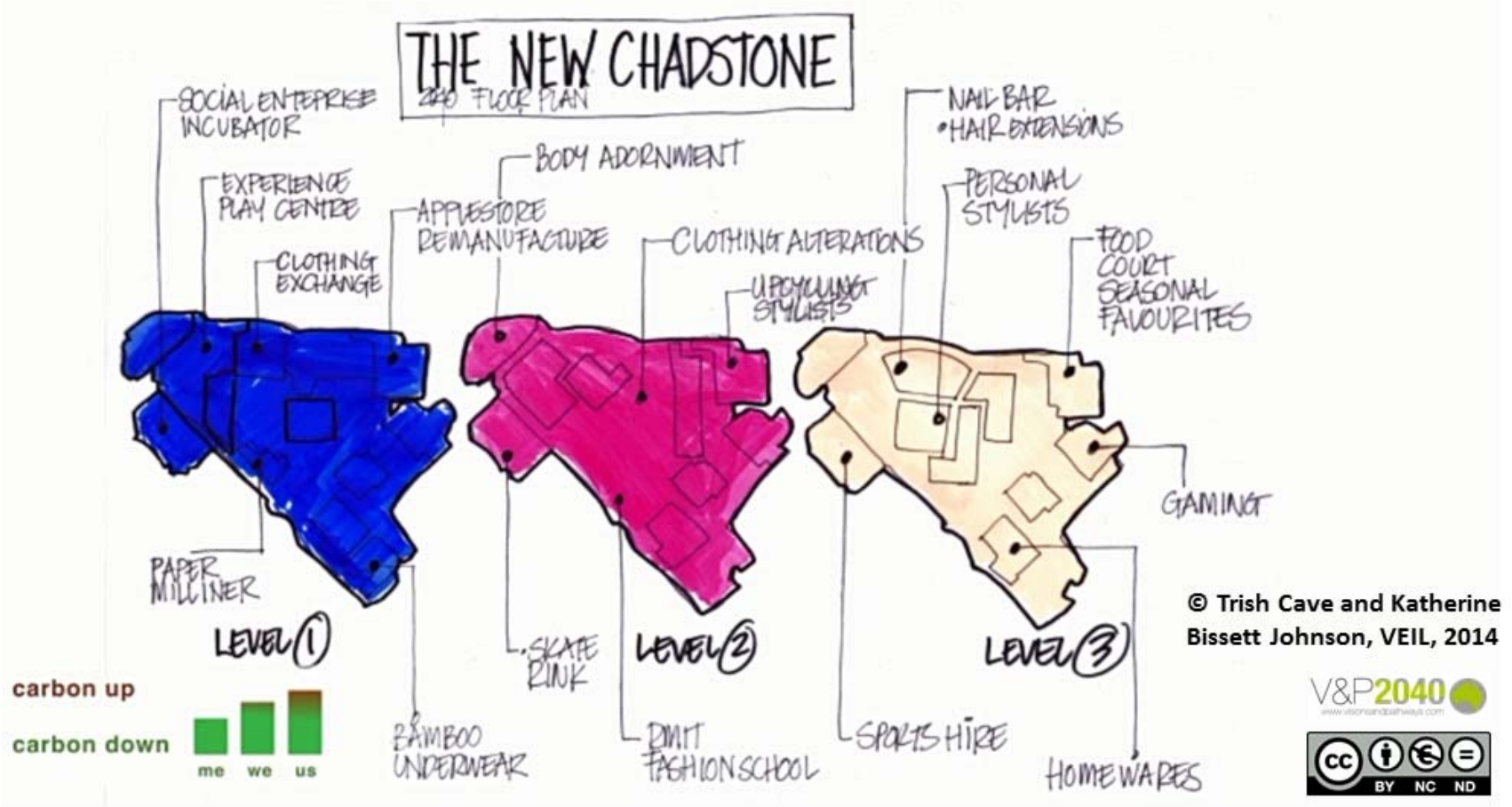

Figure 6. Large shopping centres (such as Chadstone Shopping Centre in Melbourne) are now centres of alternative forms of exchange, product "reuse" and social enterprise.

Some of the glimpses also depicted new forms of exchange (see Figure 7) and slower ways of life with improved work-life balance and more "real-here-now" contact (Figure 8 below). 


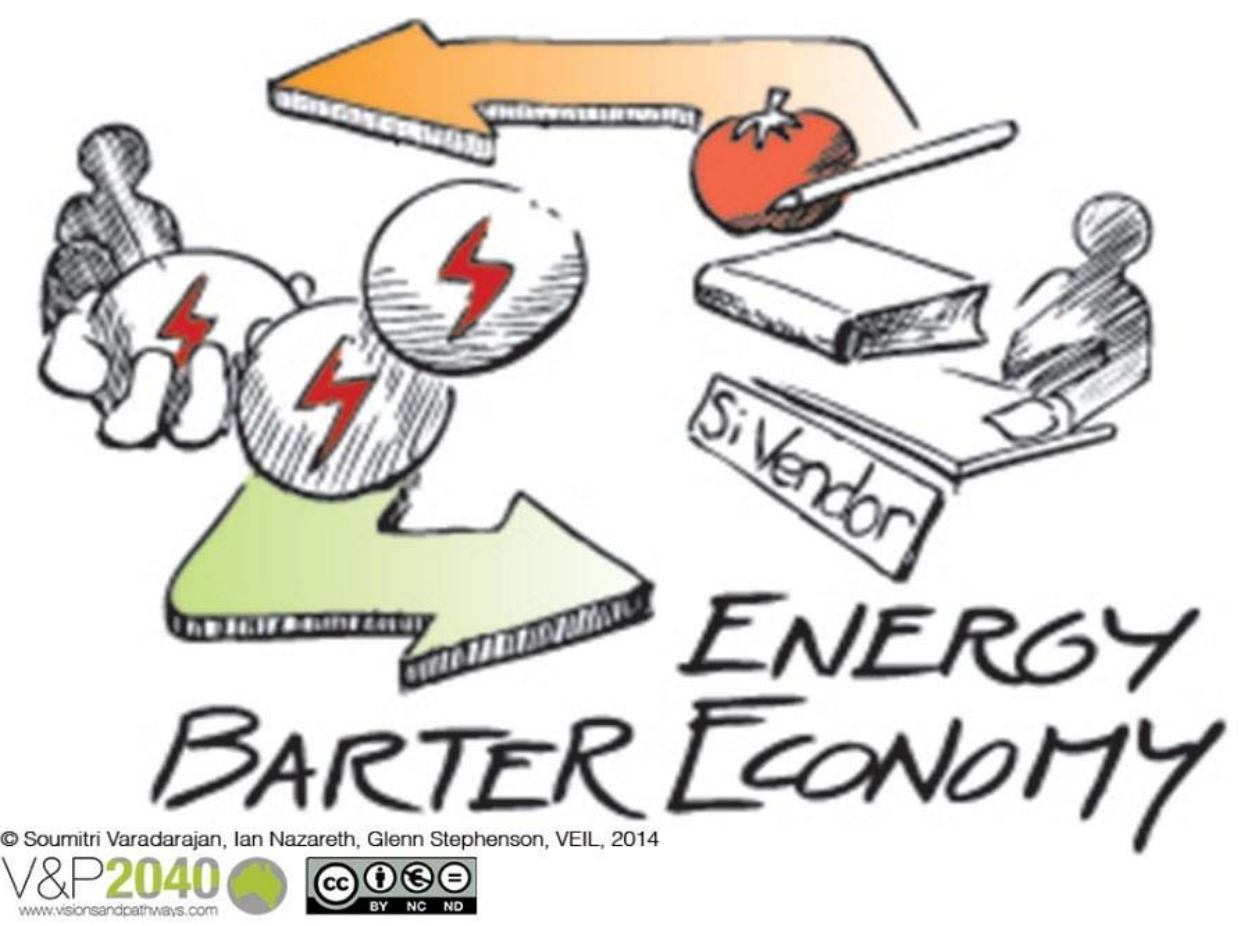

Figure 7. In Melbourne in 2040 residents routinely trade energy. For example, a household with solar panels may “trade” excess/unneeded energy for other goods/services.

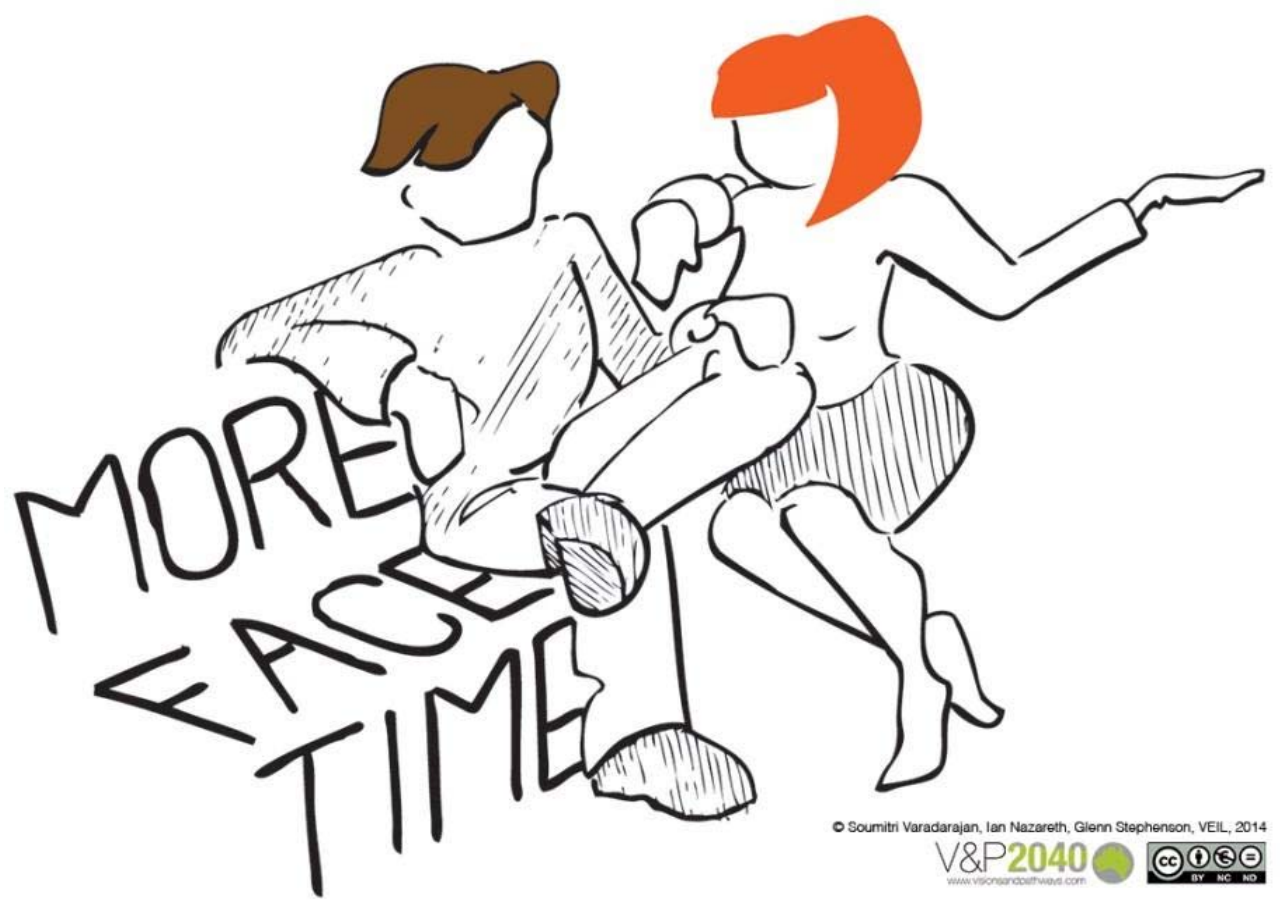

Figure 8. The balance between work and leisure/life activities and the balance between virtual social networks and "real-here-now" contact has shifted.

Major elements of this frame are summarised in the Table 4 below. 
Table 4. Summary of "radical shifts in political economy and material consumption" frame.

\begin{tabular}{|c|c|}
\hline Element & Details (in Brief) \\
\hline Diagnostic framing & $\begin{array}{l}\text { - The climate change problem is a symptom of deeper issues within } \\
\text { socio-economic systems (e.g., economic models, values) } \\
\text { - Longer-term sustainability and resilience requires socio-economic } \\
\text { transformations (not only technological and regulatory changes) }\end{array}$ \\
\hline Elements emphasised & $\begin{array}{l}\text { - } \text { Consumption (e.g., material consumption, energy consumption) } \\
\text { - } \text { Economic models } \\
\text { - } \quad \text { Cultural aspects (e.g., urban ways of life, dominant social values) } \\
\text { - } \text { Indirect greenhouse gas emissions including those generated by production } \\
\text { processes elsewhere (broader spatial boundary) }\end{array}$ \\
\hline Assumptions & $\begin{array}{l}\text { - Imminent resource and energy supply constraints demand socio-economic } \\
\text { changes which form a key part of urban resilience } \\
\text { - Climate change is not primarily a technological problem }\end{array}$ \\
\hline Primary actors & $\begin{array}{l}\text { - } \text { Citizens/city residents } \\
\text { - Social entrepreneurs } \\
\text { - } \quad \text { Activists } \\
\end{array}$ \\
\hline Subjective judgements & $\begin{array}{l}\text { - Low-carbon transitions are an opportunity for socio-economic transitions } \\
\text { (i.e., frame emphasises socio-economic goals) } \\
\text { - Communitarian values preferred over individualistic values }\end{array}$ \\
\hline $\begin{array}{l}\text { Institutional settings } \\
\text { (main themes) }\end{array}$ & $\begin{array}{l}\text { - } \quad \text { Social enterprise (e.g., social entrepreneur) } \\
\text { - NGOs/Social activist } \\
\text { - } \quad \text { Research: e.g., independent researcher }\end{array}$ \\
\hline
\end{tabular}

\subsection{Frame 3: Achieving Low-carbon Transitions through Digital Lives and "Green Orwellianism"}

Other workshop participants expressed somewhat more techno-optimist views and framed the problem in related ways. For example, some discussed the potential development of more "smart infrastructure" systems and related high-tech urban environments and envisaged ways that these could shape transport systems, workplaces and the nature of work, and leisure patterns. Some participants also speculated on the potential for advanced virtual experiences and communications technologies to reduce the need for travel and material consumption. Some participants also broadened the frame from urban resource consumption and local greenhouse gas emissions to the emissions associated with mobile modern lives. Participants who framed low-carbon transitions in this way often emphasised challenges associated with achieving substantial behavioural change. Some suggested that, in the future, high carbon behaviours could become more strongly regulated through greater transparency and real-time data, enabled by new high-tech feedback systems and surveillance systems.

A range of related disruptive forces were also nominated by some workshop participants. These included: Sensor networks; smart city technology; the growth of data, i.e., big data; digital lifestyles and further digitisation; and the adoption of "Gov 3.0" tools, technologies and techniques.

Such approaches have been termed "digital lives” and related potential systems have been termed a kind of Orwellian future, due to the potential for highly surveilled movements and associated regulation [21,22]. The former refers to the potential for the physical travel of people and objects to be substituted by forms of digital communication and virtual experiences. Additionally, more advanced digital networks of 
control and associated technologies of tracking and tracing could be used to optimise and allocate road space; enable greater automation (e.g., self-navigating vehicles); and enable the tracking, tracing and public reporting of carbon allowances and carbon expenditures [23].

For example, in one glimpse (shown in Figure 9) the carbon footprint of an urban village is made public, along with comparisons with other urban villages with a focus on energy, water, and waste. The idea is that transparency and the ability to compare performance will be a driver of change.

The so-called digital disruption was also connected to other envisaged changes to work and life. Participants expressing this framing of low-carbon, highly-resilient cities stated that they would show time travellers (who visited this future city) the following key features:

"[I'd show the "time traveler" that] work, home and play are intertwined activities, and telecommuting is the norm” [Sector: Business—specialist engineering, design and technical services; Workshop location: Sydney]

"[I'd show the "time traveler" that the] technological infrastructure exists to make remote/virtual teams the norm, rather than the exception" [Sector: Business-consultancy (Digital economy/cloud-based data analytics); Workshop location: Sydney]

"Large and small organisations embracing smart work trends that are dispersed throughout Melbourne (no more massive head offices that everyone has to travel to)—creating more co-working and collaborative opportunities, increasing productivity and happiness." [Sector: NGO; Workshop location: Melbourne]

This framing also informs some of the visualisations. Figures 9 and 10 below convey the expectation that greater transparency and monitoring will be a major driver of social change.

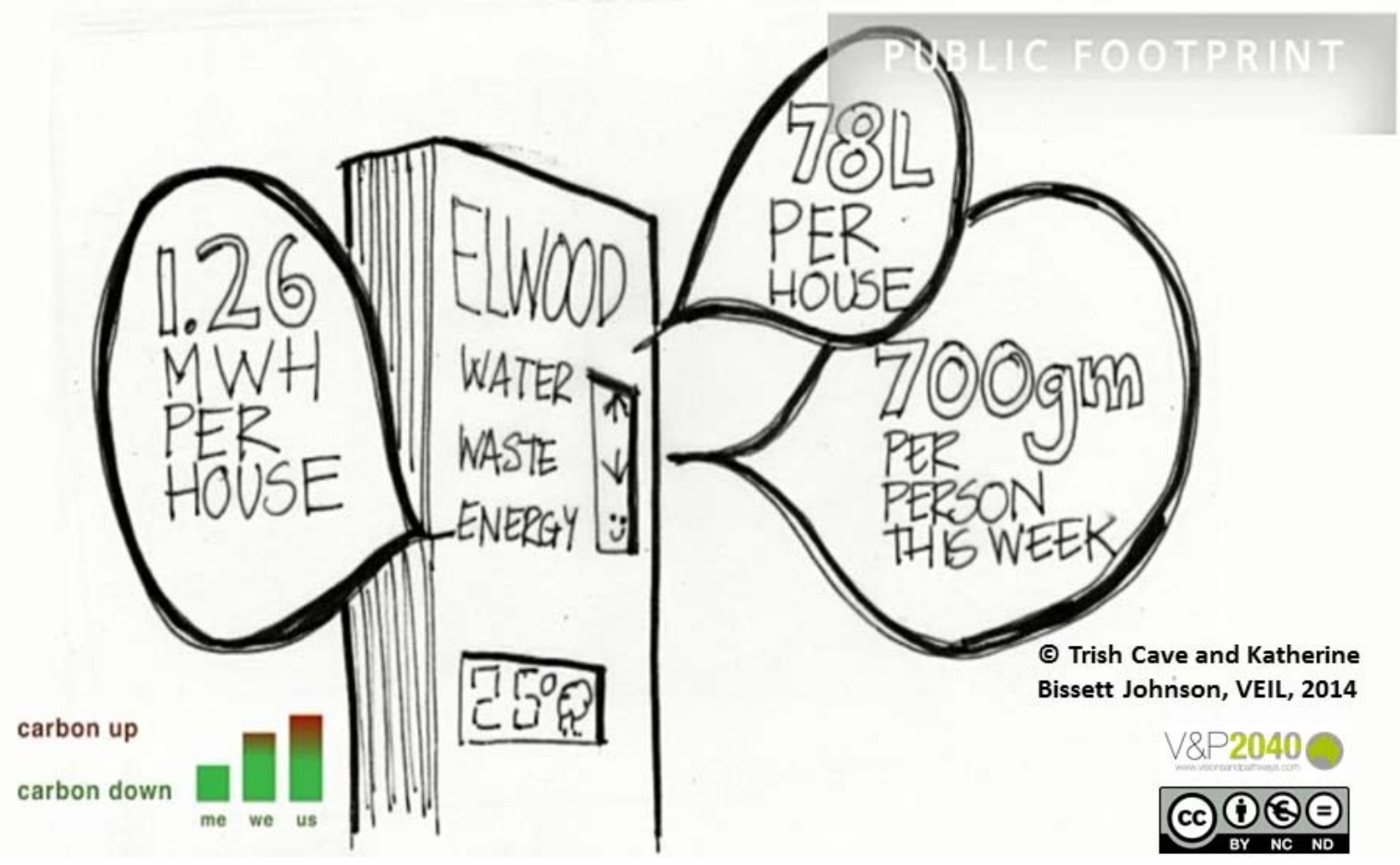

Figure 9. Public carbon footprints (precinct and household footprint data). 

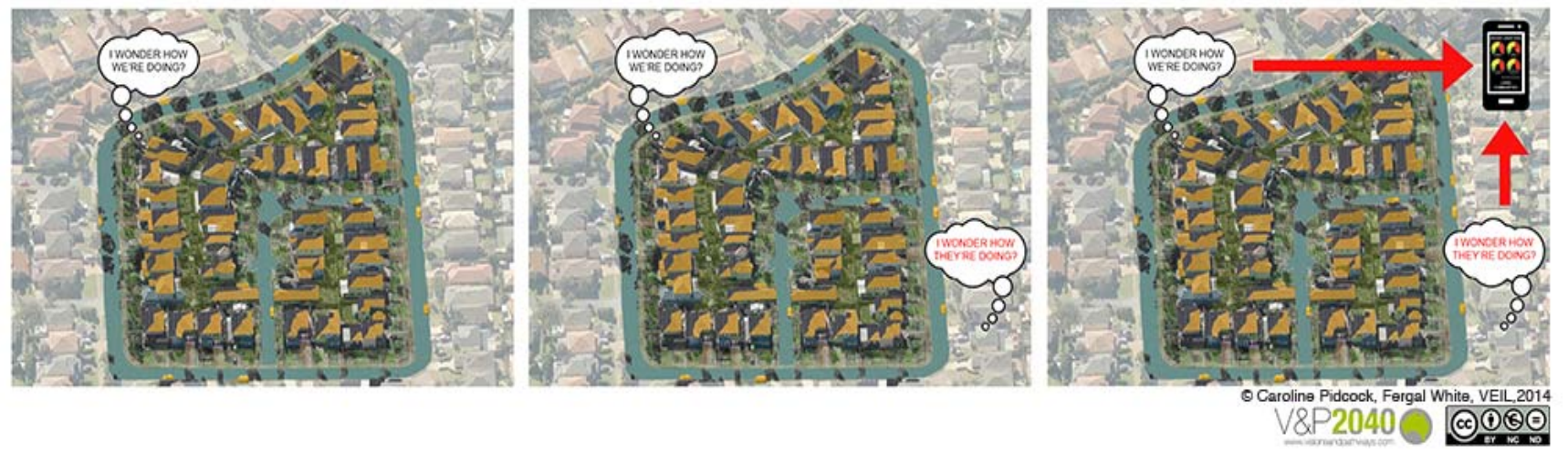

Figure 10. Neighborhood energy monitoring: Real-time energy usage and carbon footprint monitoring for each community is freely available to everyone. People can read their community's energy and carbon performance as well as that of their neighbours. Feedback and learning new ways to be more energy and carbon efficient, as well as having pride in the ecological performance of one's community, is a standard part of culture.

Similarly, real-time data analytics and wearable technologies were depicted as providing up-to-date personal footprint data, as shown in Figure 11 below. Some participants viewed related surveillance and regulatory systems as a "dictatorship of carbon” (shown in Figure 12).

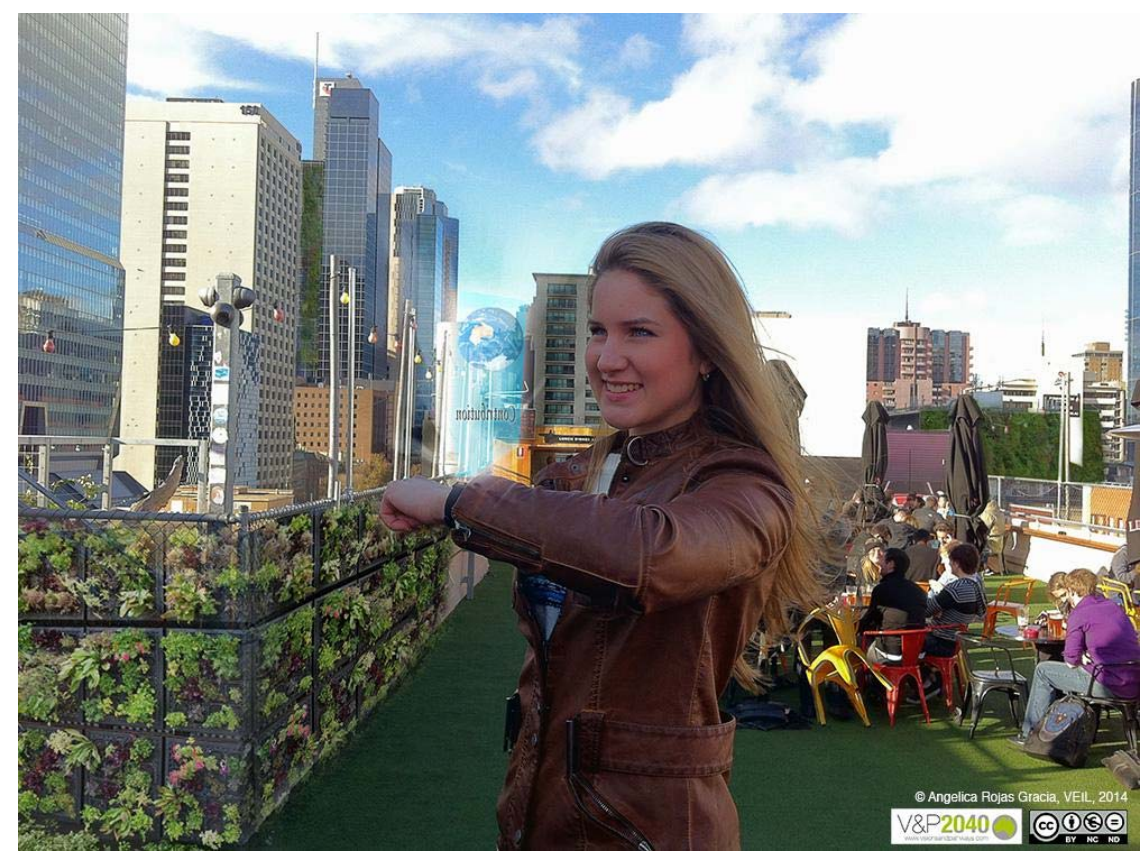

Figure 11. Use of smart wearable technologies like new wrist-bands to check a person's community "contribution index" in real-time (i.e., a current, continually updated, measurement for their "contribution" to the city or a community). Contributions could be measured in terms of energy generation, personal consumption, and participation in recycling. Such a system could also provide constantly updated data on personal contributions to greenhouse gas emissions and other impacts of personal choices/consumption. 


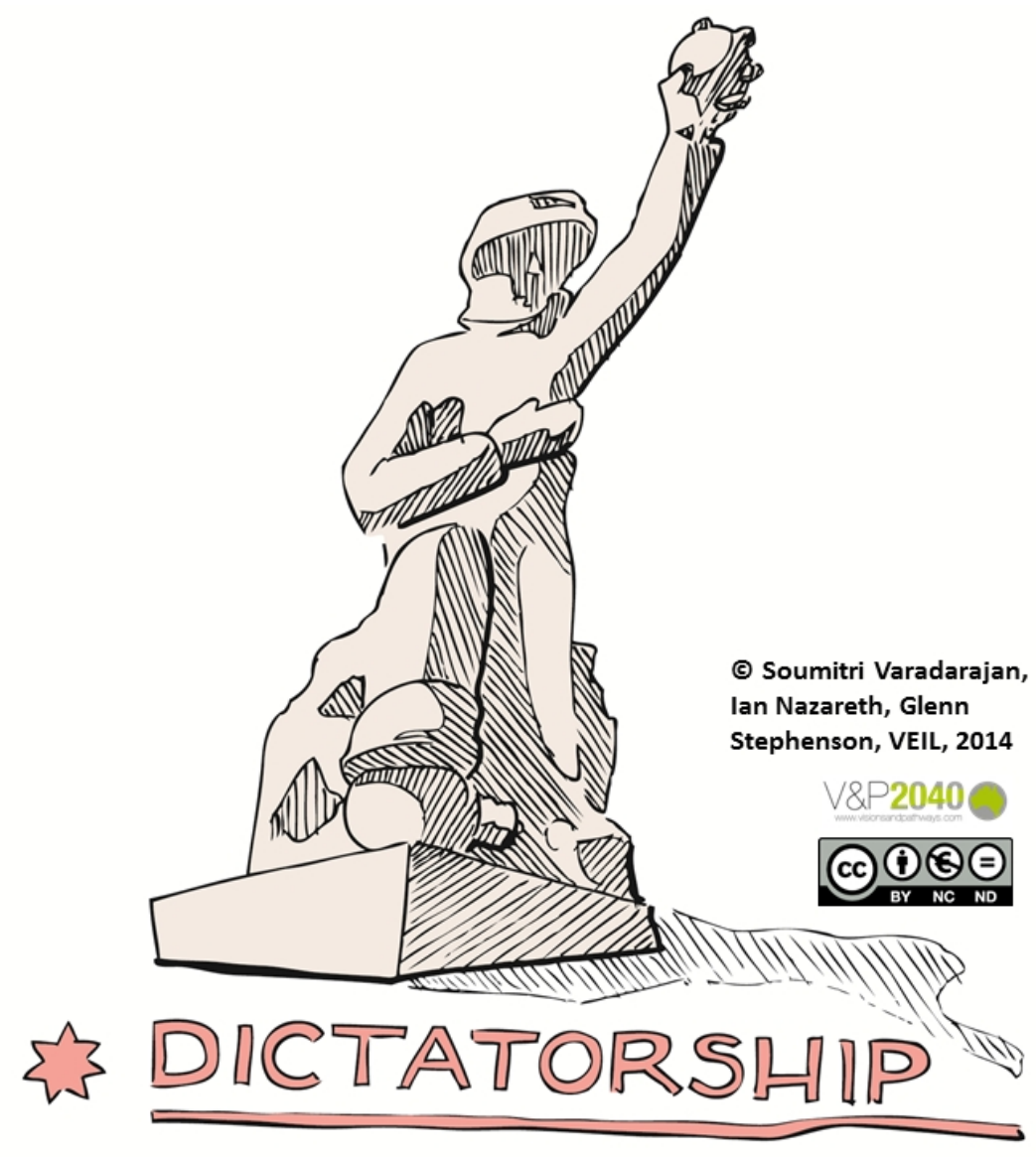

Figure 12. Strict enforcement of carbon allowances or quotas by governments, and related monitoring and regulatory systems, termed the "dictatorship of carbon”.

Major elements of this frame are summarised in Table 5 below.

Table 5. Summary of "low-carbon transitions through digital lives and green Orwellianism".

\begin{tabular}{|c|c|}
\hline Element & Details (in Brief) \\
\hline Diagnostic framing & $\begin{array}{l}\text { - Entrenched "high-carbon" behaviours which are difficult to change } \\
\text { (e.g., transport/mobility, food consumption, leisure) } \\
\text { - Contemporary modern lifestyles (including mobility expectations, } \\
\text { and related mobility requirements of work, leisure, etc.) and their } \\
\text { related resource requirements and greenhouse gas emissions }\end{array}$ \\
\hline Elements emphasised & $\begin{array}{l}\text { - Use of “smart” real-time systems to drive behavioural change } \\
\text { - Substitution of physical travel and real-world experiences } \\
\text { - } \quad \text { Low-carbon urban transitions a way to tackle urban congestion } \\
\text { and related pressures (e.g., on transport systems at peak times) }\end{array}$ \\
\hline Assumptions & $\begin{array}{l}\text { - Substitutability of real-world activities for virtual/digital activities } \\
\text { - Public acceptance of new monitoring and surveillance systems } \\
\text { - Unsustainability of contemporary mobility }\end{array}$ \\
\hline Primary actors & $\begin{array}{l}\text { - } \text { Planning professionals } \\
\text { - Private firms and public sector bodies developing and } \\
\text { administering new "smart” city and infrastructure solutions } \\
\text { - City residents }\end{array}$ \\
\hline
\end{tabular}


Table 5. Cont.

\begin{tabular}{cl}
\hline Element & Details (in Brief) \\
\hline \multirow{3}{*}{ Subjective judgements } & - Goal of shifting from high-carbon to low-carbon behaviours \\
& - Preferences for new modes of work and workplaces; \\
& - Need to revitalise suburban and regional centres \\
\hline Institutional settings & - Policy, and urban and transport planning professionals \\
(main themes) & (see Sustainable Digital Cities Network) \\
\hline
\end{tabular}

4.4. Frame 4: Advancing Urban Resilience and Climate Change Mitigation by Greening and Radically Adapting the Urban Form

The framing emphasises potential adaptation challenges facing Australian cities, given a changing and warming climate, and the potential for climatic changes to require disruptive forms of adaptation. The potential for existing buildings and urban forms to adapt to a changed climate is questioned and dystopian perspectives were also occasionally voiced. On the other hand, the potential for creatively and effectively adapting or repurposing existing urban infrastructure, buildings and systems to deal with a more extreme climate is central, as depicted in Figures 13 and 14 below. Participants who expressed this framing saw the potential to (partially) address climate and adaptation problems and achieve greater energy efficiency through additional urban greening initiatives.

For example, participants expressing this framing of low-carbon, highly-resilient cities stated that they would show time travellers (who visited this future city) the following key features:

"Community resilience networks, adaptive building design and green roofs, walls, and space has eliminated urban heat island" [Sector: State government (NSW Office of Environment and Heritage); Workshop location: Sydney]

"A city in a garden: A beautiful (nature) green city with vast parklands and plants rising up all city buildings to rooftop gardens all doing their best to absorb the CO2 in the air... [and] trails to everywhere... A Melbourne Food Bowl: A city producing organic food for residents” [Sector: State government (Parks Victoria); Workshop location: Melbourne]

"There is substantial green tree planting where possible-perhaps 30-40 per cent of the city is covered in greenery such as trees as it is a good foil for reducing heat from heat waves. There are sea walls built around the main city foreshore to prevent storm surges. Storm water harvesting systems have been installed around Sydney to capture and purify all the water.” [Sector: Business: Environmental consultant; Workshop location: Melbourne]

"Vegetative cooling technologies; water reuse and recycling and urban food production on rooftops across the city." [Sector: Business: Environmental consultant; Workshop location: Melbourne]

"The greening of concrete corridors, with vine-covered paths that are "air-conditioning" the passage of pedestrians and cyclists” [Sector: Media/Creative Arts; location: Melbourne] 
Many participants envisaged, in a range of ways, related changes to create far greener cities. For example, in the survey responses the followings sorts of changes were envisaged:

- Protected urban and peri-urban "green lungs";

- Green public spaces; greened inner city precincts; green urbanity;

- Mitigating the urban heat island effect with green roof infrastructure (e.g., comprehensive green roof coverage) and greater urban greening (tree planting, other greenery in the CBD);

- Major urban flora and food planting;

- Permaculture and green spaces all through the city and broader metro area providing food and leisure (recreation) opportunities; and

- Greater urban biodiversity.

Related, future disruptive forces were also nominated by some workshop participants-especially those in the natural environment. These included: Increased frequency of major heatwave events/increased heat; drought and fire; climate change (more broadly); disruption of the seasons and agricultural production; and water scarcity. A related positive disruptive force stated by another participant stated was "more green spaces to deal with heat stress", and a related negative force is the "collapse of keystone species e.g., bees, bats, and birds concerning so need to support biodiversity in our cities”. Some participants expected that infrastructure failures will be a disruptive force.

This framing also informs some of the visualisations that were developed. Some glimpses portray a city in which climate change led to the repurposing of abandoned buildings and unusable infrastructure (Figures 13 and 14 below) and urban greening provides a way to cool buildings (Figure 15).

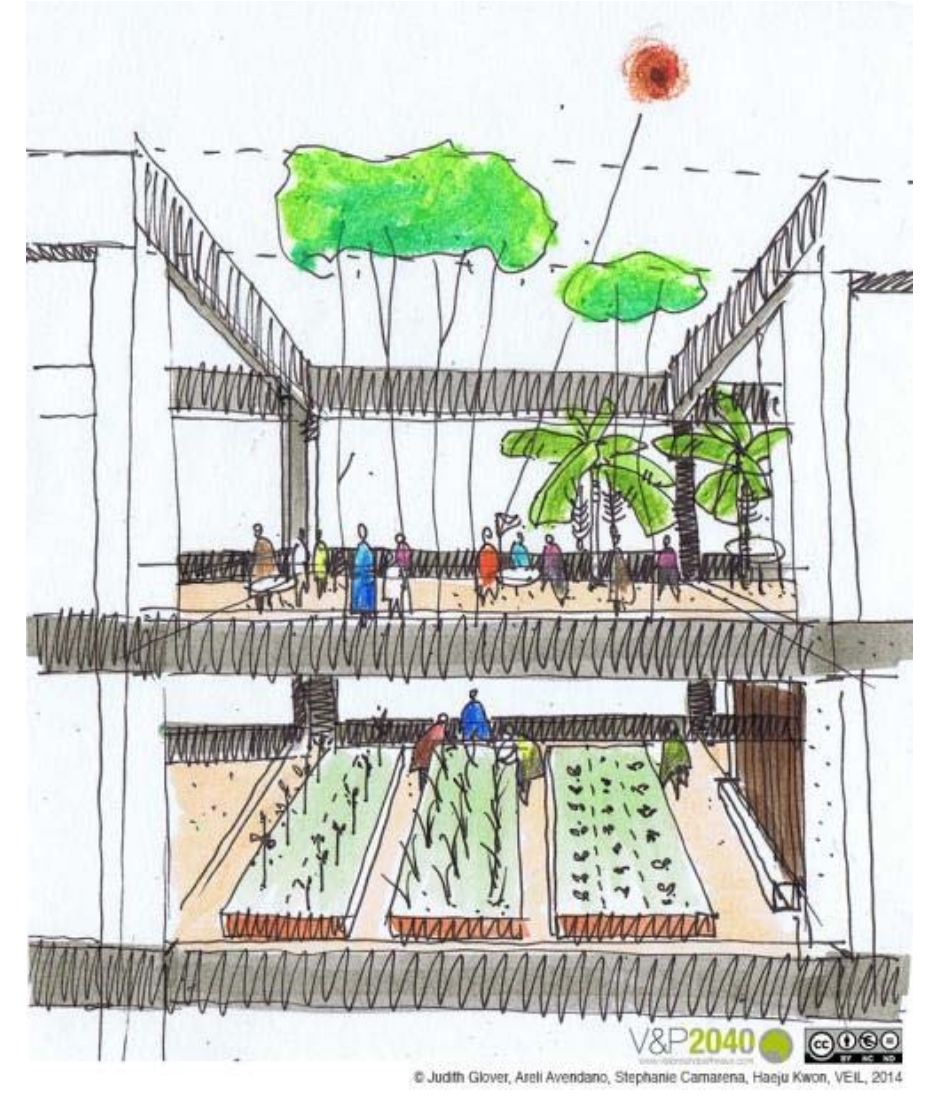

Figure 13. An abandoned building now being used as an urban greenhouse. 


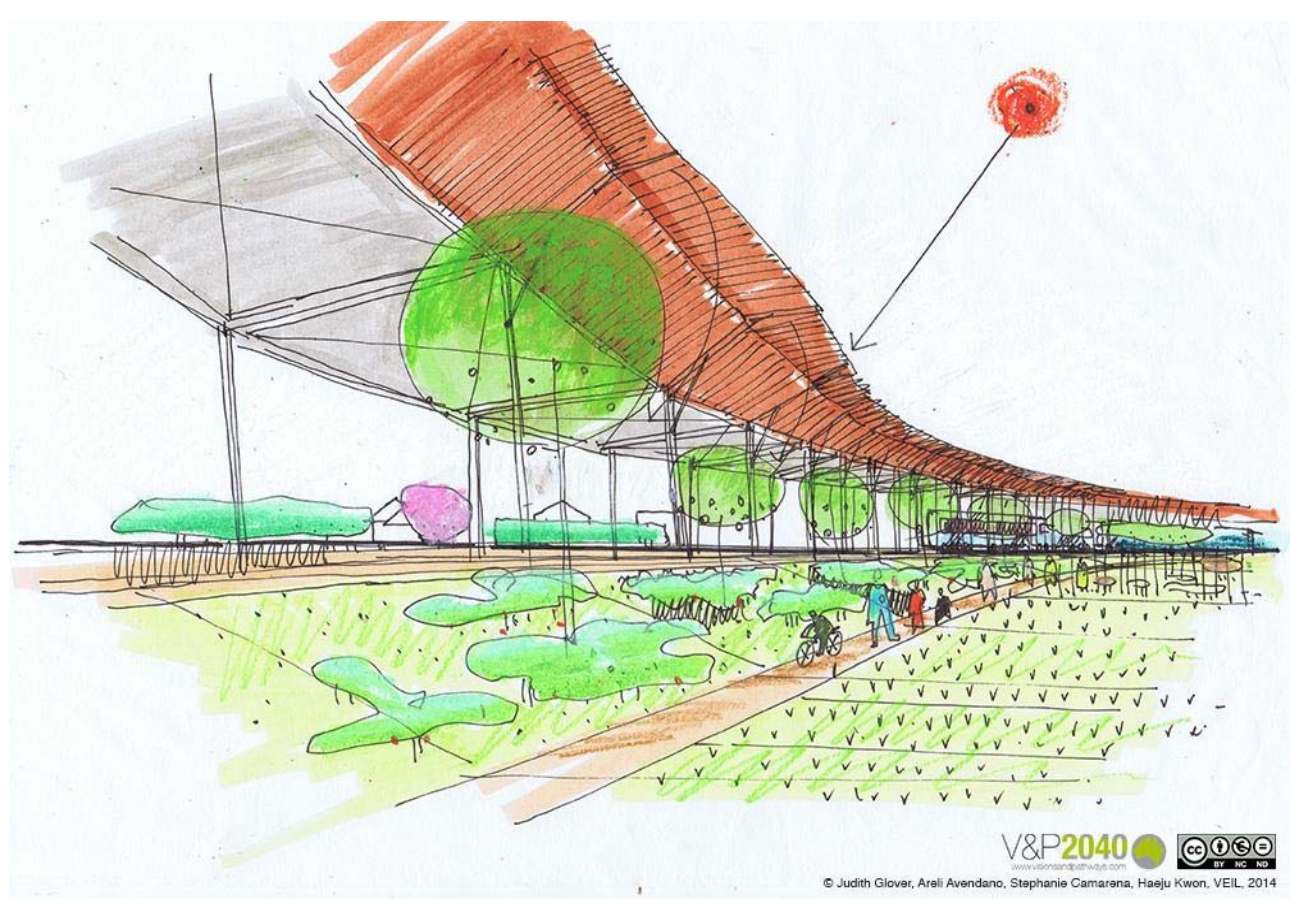

Figure 14. New uses of existing infrastructure to enable new forms of adaptation to extreme climates: Example of reclaimed land under former freeways being used for new purposes due to protection from sun and other climate extremes.

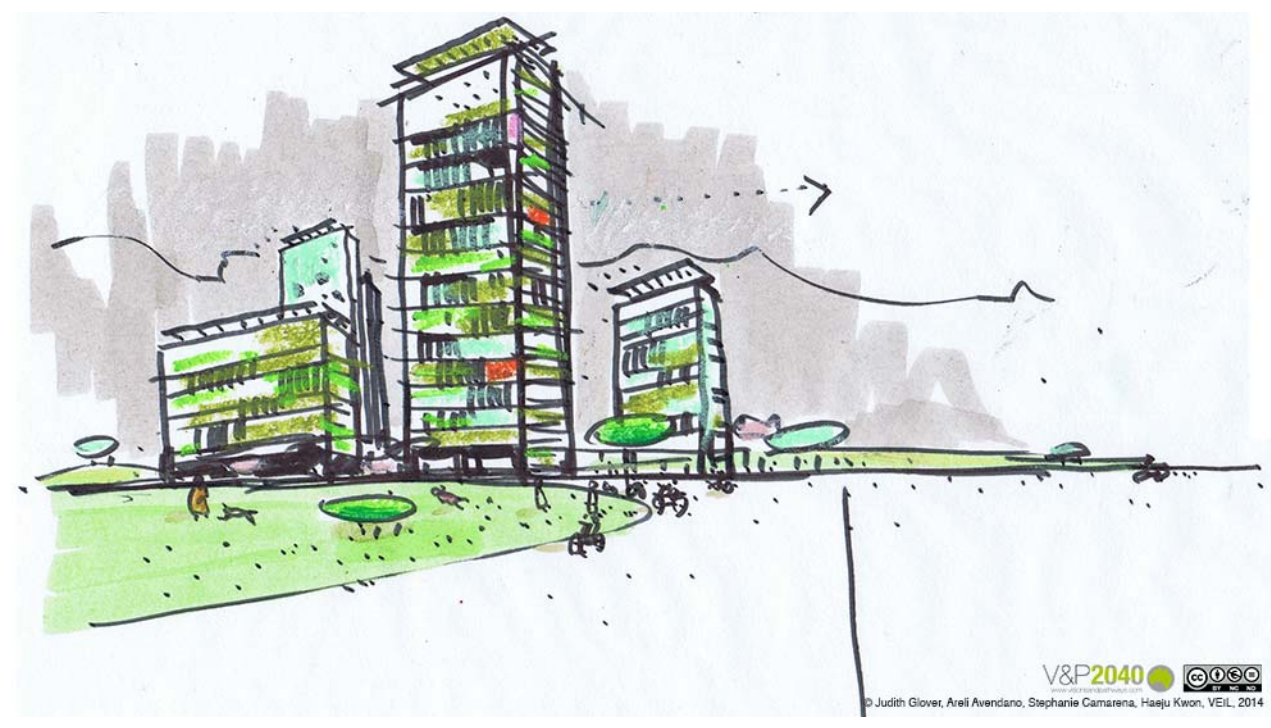

Figure 15. A breeze blows through and cools buildings in Melbourne 2040. Buildings are living systems and use vegetation as permeable "skins".

Additional glimpses conveyed other forms of "extreme" adaptation to climate change. For example, one glimpse depicts a shift to living underground termed "burrowing" (Figure 16). 


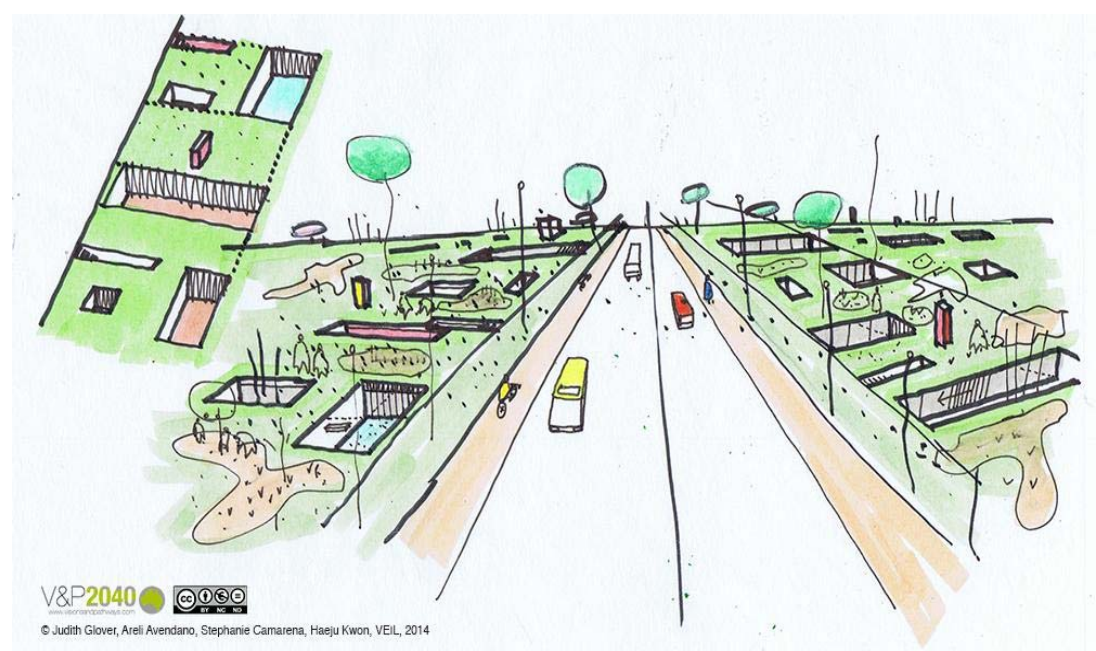

Figure 16. The concept of "burrowing" and building houses underground is mainstream in 2040. This Melbourne suburb consists of underground houses that escape extremes of heat and bushfires on the urban fringe. The backyard is now the "top yard", and is used for recreation, food production and natural habitats. This provides climate protection, decreases energy costs and provides a greater sense of connection to nature.

Major elements of this frame are summarised in Table 6 below.

Table 6. Summary of the "Advancing resilience and climate change mitigation by greening and adapting the urban form” frame.

\begin{tabular}{|c|c|}
\hline Element & Details (in Brief) \\
\hline Diagnostic framing & $\begin{array}{l}\text { - Risks to urban resilience posed by climate change/extreme events } \\
\text { - Urban forms and "environments" as providing a constructed barrier } \\
\text { between human beings and nature (e.g., extreme weather events) } \\
\text { - Role of urban/spatial forms in "locking-in" consumption (e.g., energy) }\end{array}$ \\
\hline Elements emphasised & $\begin{array}{l}\text { - Local-level adaptive action, i.e., a human settlement focus } \\
\text { - Existing urban infrastructure: Repurposing buildings/structures } \\
\text { - Links between the built/urban form and experienced climates }\end{array}$ \\
\hline Assumptions & $\begin{array}{l}\text { - More substantive warming and climate impacts over the next } 25 \text { years } \\
\text { (by 2040)-e.g., increasing weather-related natural disasters and losses } \\
\text { (e.g., droughts, fire threat), heat stress effects, etc.-and more extreme } \\
\text { forms of "preparedness" and adaptation required } \\
\text { - Local climate adaptation actions often also have mitigative functions } \\
\text { (e.g., urban greening programs reducing energy consumption) }\end{array}$ \\
\hline Primary actors & $\begin{array}{l}\text { - Local and state governments } \\
\text { - City residents } \\
\text { - Urban foresters and urban biodiversity experts } \\
\text { - Research organisations }\end{array}$ \\
\hline Subjective judgements & $\begin{array}{l}\text { - Existing major settled areas should be retained (rather than being } \\
\text { abandoned), even in the event of catastrophic climate change } \\
\text { - We should maintain existing outdoor lifestyles and leisure activities }\end{array}$ \\
\hline $\begin{array}{l}\text { Institutional settings } \\
\text { (main themes) }\end{array}$ & $\begin{array}{l}\text { - Local Government } \\
\text { - State Government Department/Agencies } \\
\text { - Consultancy (e.g., environmental; communications e.g., media/creative) }\end{array}$ \\
\hline
\end{tabular}




\subsection{Frame 5: Low-Carbon Transitions as Changes to City-Scale Infrastructure and Larger-Scale Systems}

Other participants, when asked to state what had changed between 2014 and 2040 that they would show to a time traveller from 2014 who visited the city (i.e., Melbourne or Sydney) in 2040, focussed on changes to city-scale hard infrastructure and related changes to large-scale systems such as for regional transport (e.g., inter-state high-speed rail) and changes to the national electricity grid. This was sometimes linked to changes in public policy or changes in behaviour (e.g., increased cycling).

The following responses to the survey questions are also illustrative of this particular frame:

"[I'd show the "time traveler" the] extensive punctual and widespread underground railway system, superior to New York, Hong Kong, Paris and London; car free city centre with plenty of bicycle parking facilities; and numerous district renewable energy generation mini grids with storage that have completely replaced the need for brown coal fired power generation from one central grid." [Sector: Business-renewable energy/clean energy sector; Workshop location: Melbourne]

"[I'd show the "time traveler" the] high speed rail station delivering passengers to Australia's major cities in record time, replacing air travel... and all the light rail public transport making so many outlying areas of Melbourne accessible to the city" [Sector: Media/Creative Arts; Workshop location: Melbourne]

"Fast train network from the CBD to our airports, renewable energy generation facilities near to Melbourne, safe and linked access routes for cycling into and out of the city..." [Sector: Business: Renewable energy firm; workshop location: Melbourne]

"A reactivated Sydney Harbour used for transport and aquaculture. The Sydney Harbour Tidal Barrage” [Sector: Business—urban systems/built environment consultant: Location: Sydney]

"There are no cars in the city—a second city loop [underground train system/network] and a series of tree-lined walking/cycling paths make it easy to get around... [and] there are six new rail lines going out to the suburbs and an outer suburban loop 100\% renewable powered public transport network.” [Sector: Local Government; Workshop location: Melbourne]

"Mass transport for produce and big things in special freeway zones-possibly underground - which is high speed and automated; large tubes dispersing goods and produce.” [Sector: Peak body (Green building industry); workshop location: Melbourne]

Related, future disruptive forces were also nominated by some workshop participants, such as: High speed rail; clean transport technologies being available right now; cost effective large-scale renewable energy; and increasing interest in and decreasing costs of renewable energy. Another respondent suggested that "current infrastructure not [being] up to scratch" would be a disruptive force.

Some participants pointed to related technical changes and potential innovations that could lead towards low-carbon resilience cities, particularly for buildings, transportation and energy, e.g.,

- Electric cars and busses;

- Driverless vehicles; 
- Highly efficient buildings that minimise energy use and the use of other resources;

- Distributed energy generation and new storage technologies;

- Advanced battery-assisted cycles (e-bikes/commuter bikes); and

- New transport infrastructure such as for cycling throughout the city (such as the cycling highway shown in Figure 17) and inter-city high-speed rail services (Figure 18).

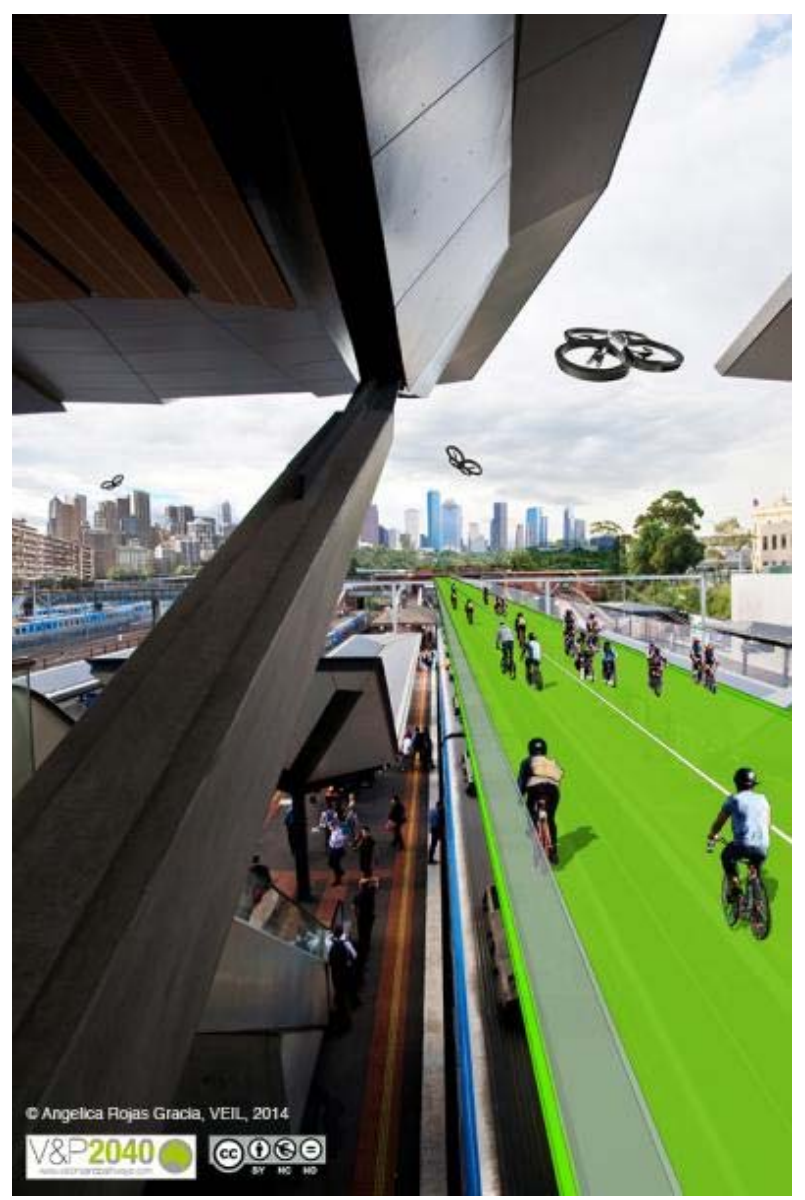

Figure 17. A Melbourne train station in 2040, next to an elevated cycling highway. The drones in the sky are part of a delivery system, in which post and other goods are distributed.

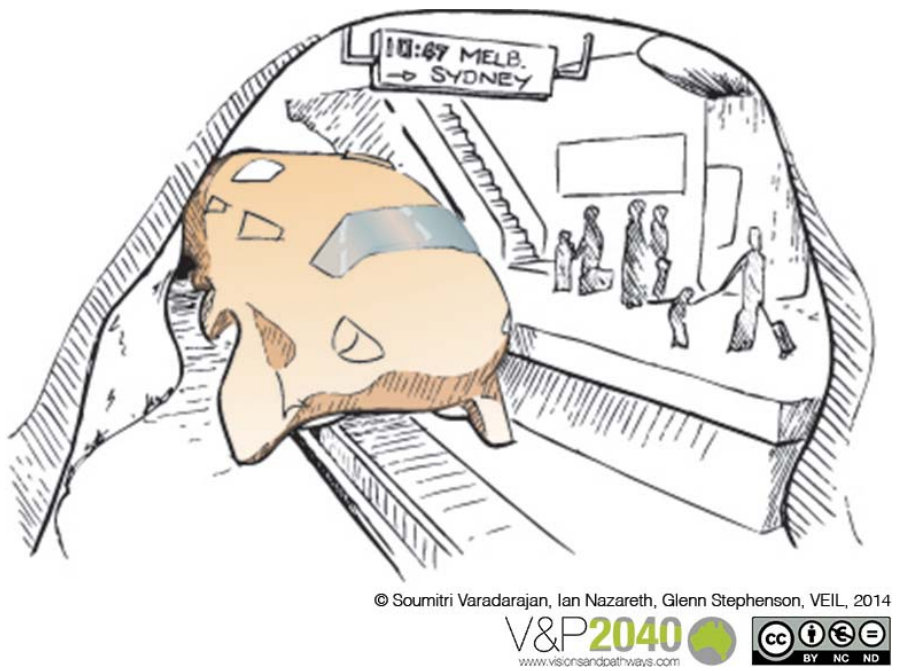

Figure 18. High speed trains link Australian cities in 2040, negating the need to fly for business travel. 
Major elements of this frame are summarised in Table 7 below.

Table 7. Summary of "low-carbon transitions as changes to city-scale infrastructure and larger-scale systems” frame.

\begin{tabular}{|c|c|}
\hline Element & Details (in Brief) \\
\hline Diagnostic framing & $\begin{array}{l}\text { - Major changes to major public and enabling infrastructure (such as } \\
\text { for transport, energy) are required for low-carbon transitions } \\
\text { - Lack of funding for alternative lower-emissions infrastructure (e.g., } \\
\text { lack of funding for expanding public transport systems) }\end{array}$ \\
\hline Elements emphasised & $\begin{array}{l}\text { - Larger-scale, hard infrastructure-city-scale, regional, national } \\
\text { - Emphasises transport and energy; less focus on consumption and } \\
\text { other sources of emissions (e.g., agriculture/food production) } \\
\text { - Technical change/technological innovation }\end{array}$ \\
\hline Assumptions & $\begin{array}{l}\text { - Services such as high-speed rail between State capitals are viable } \\
\text { - It is in the public interest to sustain national hard infrastructure over } \\
\text { the long-term (e.g., the national grid supplying cities) }\end{array}$ \\
\hline Primary actors & $\begin{array}{l}\text { - Federal/State governments (infrastructure investment and policy) } \\
\text { - Other relevant public sector bodies } \\
\text { - Electricity sector and firms } \\
\text { - Construction sector and firms }\end{array}$ \\
\hline Subjective judgements & $\begin{array}{l}\text { - Preference for "big infrastructure" solutions to social problems } \\
\text { - } \quad \text { Related relevant expertise includes engineering and financing }\end{array}$ \\
\hline $\begin{array}{l}\text { Institutional settings } \\
\text { (main themes) }\end{array}$ & $\begin{array}{l}\text { - Infrastructure provision } \\
\text { - Renewable energy companies/clean energy sector } \\
\text { - Built environment organisations }\end{array}$ \\
\hline
\end{tabular}

Overall, the frames can be summarised by outlining each diagnostic frame (i.e., the way that the problem was described and/or explained) and the associated prognostic framing (i.e., prescriptions for addressing the problem). The five frames are summarised in Table 8 below:

Table 8. Summary of identified frames.

\begin{tabular}{|c|c|c|}
\hline Frame & Diagnostic Framing & Prognostic Framing \\
\hline $\begin{array}{l}\text { Localised urban } \\
\text { sustainability }\end{array}$ & $\begin{array}{l}\text { Urban low-carbon transitions and } \\
\text { resilience requires a new logic of urban } \\
\text { (re)development, which incorporates } \\
\text { greater localised self-reliance. }\end{array}$ & $\begin{array}{l}\text { - } \text { Self-reliance; distributed systems. } \\
\text { - Transformation of precincts and/or } \\
\text { suburbs (citizen-led) via localised } \\
\text { emergent mobilisation and community } \\
\text { engagement. The state acts as an } \\
\text { enabler, changing planning frameworks } \\
\text { and enabling "polycentric" forms. }\end{array}$ \\
\hline $\begin{array}{l}\text { Radical shifts in } \\
\text { political economy } \\
\text { and consumption }\end{array}$ & $\begin{array}{l}\text { The climate change problem is a } \\
\text { symptom of deeper issues with existing } \\
\text { socio-economic systems. Longer-term } \\
\text { sustainability and resilience requires } \\
\text { socio-economic transformations. }\end{array}$ & $\begin{array}{l}\text { - Radical changes to patterns of } \\
\text { consumption and reorganisation of } \\
\text { the structure of economies. } \\
\text { - Institutional transformation required } \\
\text { for urban low-carbon transitions }\end{array}$ \\
\hline
\end{tabular}


Table 8. Cont.

\begin{tabular}{|c|c|c|}
\hline Frame & Diagnostic Framing & Prognostic Framing \\
\hline $\begin{array}{l}\text { Digital lives and } \\
\text { "green } \\
\text { Orwellianism” }\end{array}$ & $\begin{array}{l}\text { Social and technological barriers to } \\
\text { changing existing high-carbon } \\
\text { behaviours (e.g., travel, meat-intensive } \\
\text { diets, material consumption). }\end{array}$ & $\begin{array}{l}\text { - Use of informational and "smart" } \\
\text { technologies to enable major shifts } \\
\text { from high-carbon to low-carbon } \\
\text { behaviours and to drive such changes. }\end{array}$ \\
\hline $\begin{array}{l}\text { Greening and } \\
\text { radically adapting the } \\
\text { urban form }\end{array}$ & $\begin{array}{l}\text { Urban environmental risks associated } \\
\text { with climate change, are presenting } \\
\text { cities with significant, emerging } \\
\text { challenges (e.g., adaptation to } \\
\text { dynamic new climate risks). }\end{array}$ & $\begin{array}{l}\text { - "Mitigative adaptation”: Adapt urban } \\
\text { form to address climate change and } \\
\text { risks; exploit mitigation co-benefits } \\
\text { (e.g., reduced energy use) } \\
\text { - Creatively repurposing existing urban } \\
\text { structures and existing buildings. }\end{array}$ \\
\hline $\begin{array}{l}\text { Changes to } \\
\text { city-scale "hard" } \\
\text { infrastructure and } \\
\text { large-scale systems }\end{array}$ & $\begin{array}{l}\text { Urban and broader low-carbon } \\
\text { transitions demand major changes to } \\
\text { public infrastructure and associated } \\
\text { enabling "hard" infrastructure. }\end{array}$ & $\begin{array}{l}\text { - New city-scale, regional and national } \\
\text { infrastructure (“technical fixes”) to } \\
\text { increase the resilience of infrastructure, } \\
\text { and support low-carbon living. }\end{array}$ \\
\hline
\end{tabular}

\subsection{Dominant and Alternative Frames}

The "localised urban sustainability" frame was the dominant frame in both the Melbourne and Sydney workshops, although adherents to all five frames were present at both workshops. This is reflected in the work of the designers/design teams, with the work of seven (out of nine) strongly expressing the prognosis emphasised by frame 1 . Frame 5 was expressed by fewest designers/design teams (two designers/design teams). This finding surprised some project members who had previously encountered resistance to similar concepts emphasising re-localisation and more distributed systems (with energy, food and water production embedded in urban landscapes), such as the vision of a future multi-local "city of short distances” which was developed in the Melbourne 2032 project which was also led by the Victorian Eco-Innovation Lab (VEIL). This result may be reflective of the mainstreaming of such ideas, at least within the built environment sector. In recent years, metropolitan planning strategies in Australia have increasingly emphasised ideas such as "infill” (as per the concept of more compact cities), polycentric urban forms, walkability and living more locally within your neighbourhood (e.g., as per increasing focus on making Melbourne a so-called "20 minute city"), along with the increased investment in photovoltaic solar power technologies in Australian cities. An alternative, or complementary, explanation is that the dominance of the frame is an artifact of the sample, i.e., influenced by who did and didn't participate, their institutional and/or life settings [14], and/or their ideological leanings [11]. These aspects are further discussed below.

\subsection{Identified and Potential Framing Processes}

\subsubsection{Evidence of the Influence of Framing Processes and Related Social Processes}

Framing theorists argue that frames are co-constituted by the "particular institutional, political and life settings" of actors [14]. The survey data provides some evidence of this. For example, "localised urban sustainability" was the dominant frame of those working in a specific local setting (e.g., 
participants who work in local government) or whose work otherwise focusses on specific places (e.g., precincts). "Radical shifts in political economy and consumption" was the dominant frame of participants from social enterprises, NGOs and the research sector (and not those from government and business). The two respondents from State government agencies (Parks Victoria and the New South Wales Office of Environment and Heritage) emphasised "advancing resilience and climate change mitigation by greening and adapting the urban form” (Frame 4). Respondents from specialty built environment and/or large infrastructure-related consulting firms (e.g., AECOM) and utilities emphasised "Changes to city-scale "hard” infrastructure and large-scale systems" (Frame 5). These patterns are indicative of the ways that frames are co-constituted by actors' settings.

Table 9 below compares the frames expressed by some of the categories of participants who responded to the pre-workshop survey (i.e., from different institutional and life settings).

Table 9. Main frames expressed by participant category.

\begin{tabular}{|c|c|c|c|}
\hline Sector & Category & $\begin{array}{l}\text { Dominant Frame(s) } \\
\text { in Survey Responses }\end{array}$ & $\begin{array}{l}\text { Other Frames Evident in } \\
\text { Survey Responses }\end{array}$ \\
\hline \multirow{3}{*}{ Business } & $\begin{array}{l}\text { Urban design/related } \\
\text { practice }(n=8)\end{array}$ & $\begin{array}{l}\text { Frame 1: "Localised } \\
\text { urban sustainability" } \\
\text { (7 of } 8 \text { responses) }\end{array}$ & $\begin{array}{l}\text { - Frame 5: "Changes to } \\
\text { city-scale "hard” infrastructure } \\
\text { and large-scale systems" } \\
\text { (3 of } 7 \text { responses) } \\
\text { - Frame 2: "Radical shifts in } \\
\text { political economy and } \\
\text { consumption (3 of 7) }\end{array}$ \\
\hline & $\begin{array}{l}\text { Specialty built environment } \\
\text { and/or large infrastructure- } \\
\text { related consulting firm, e.g., } \\
\text { engineering and/or } \\
\text { construction services }(n=6)\end{array}$ & $\begin{array}{l}\text { Frame 5: "Changes to } \\
\text { city-scale "hard" } \\
\text { infrastructure and } \\
\text { large-scale systems" } \\
\text { (5 of } 6 \text { responses) }\end{array}$ & $\begin{array}{l}\text { - Frame 1: “Localised } \\
\text { urban sustainability” } \\
\text { (2 of } 6 \text { responses) } \\
\text { - Frame 3: Digital lives and } \\
\text { "green Orwellianism } \\
\text { (1 of } 6 \text { responses”) }\end{array}$ \\
\hline & $\begin{array}{l}\text { Consultancy-general } \\
\text { sustainability-related or } \\
\text { environmental }(n=5)\end{array}$ & $\begin{array}{l}\text { Frame 1: "Localised } \\
\text { urban sustainability” } \\
\text { (4 of } 5 \text { responses) }\end{array}$ & $\begin{array}{l}\text { - Frame 4: Greening and } \\
\text { radically adapting urban } \\
\text { form ( } 3 \text { of 5) } \\
\text { - Frame 2: "Radical shifts in } \\
\text { political economy and } \\
\text { consumption (2 of 5) } \\
\text { - Frame 5: "Changes to } \\
\text { city-scale "hard" infrastructure } \\
\text { and large-scale systems" } \\
\text { (2 of } 5 \text { responses) }\end{array}$ \\
\hline Government & Local government $(n=7)$ & $\begin{array}{l}\text { Frame 1: "Localised } \\
\text { urban sustainability" } \\
\text { (5 of } 7 \text { responses) }\end{array}$ & $\begin{array}{l}\text { - Frame 2: "Radical shifts } \\
\text { in political economy and } \\
\text { consumption (3 of 7) } \\
\text { - Frame 5: "Changes to } \\
\text { city-scale "hard” infrastructure } \\
\text { and large-scale systems" (2 of } \\
7 \text { responses) }\end{array}$ \\
\hline
\end{tabular}


Table 9. Cont.

\begin{tabular}{|c|c|c|c|}
\hline Sector & Category & $\begin{array}{l}\text { Dominant Frame(s) in } \\
\text { Survey Responses }\end{array}$ & $\begin{array}{l}\text { Other Frames Evident in } \\
\text { Survey Responses }\end{array}$ \\
\hline Government & $\begin{array}{l}\text { State government } \\
\text { agency/department }(n=2)\end{array}$ & $\begin{array}{l}\text { Frame 4: “Advancing } \\
\text { resilience and climate } \\
\text { change mitigation by } \\
\text { greening and adapting the } \\
\text { urban form” ( } 2 \text { of } 2)\end{array}$ & $\begin{array}{l}\text { - Frame 1: "Localised urban } \\
\text { sustainability” ( } 1 \text { of } 2 \\
\text { responses) }\end{array}$ \\
\hline Utilities & $\begin{array}{l}\text { Energy } \\
\text { distribution/generations } \\
\text { [Ausgrid, Pacific Hydro] } \\
(n=2)\end{array}$ & $\begin{array}{l}\text { Frame 5: "Changes to } \\
\text { city-scale "hard" } \\
\text { infrastructure and large-scale } \\
\text { systems" ( } 2 \text { of } 2 \text { responses) }\end{array}$ & - NONE \\
\hline \multirow{3}{*}{ Other } & $\begin{array}{l}\text { Research ( } n=9 \\
\text { [excluding Ph.D. } \\
\text { students]) }\end{array}$ & $\begin{array}{l}\text { Frame 2: "Radical shifts in } \\
\text { political economy and } \\
\text { consumption ( } 6 \text { of } 9 \text { ) }\end{array}$ & $\begin{array}{l}\text { - Frame 1: "Localised } \\
\text { urban sustainability" } \\
\text { (4 of } 9 \text { responses) } \\
\text { - Frame 5: "Changes to } \\
\text { city-scale "hard” } \\
\text { infrastructure and large-scale } \\
\text { systems" (2 of } 9 \text { responses) } \\
\end{array}$ \\
\hline & Social enterprise $(n=3)$ & $\begin{array}{l}\text { Frame 2: "Radical shifts in } \\
\text { political economy and } \\
\text { consumption ( } 3 \text { of } 3 \text { ) }\end{array}$ & $\begin{array}{l}\text { Frame 1: "Localised } \\
\text { urban sustainability” } \\
\text { (2 of } 3 \text { responses) }\end{array}$ \\
\hline & NGOs $(n=3)$ & $\begin{array}{l}\text { Frame 2: "Radical shifts } \\
\text { in political economy } \\
\text { and consumption } \\
\text { ( } 2 \text { of } 3 \text { responses) } \\
\text { Frame } 1 \text { : "Localised } \\
\text { urban sustainability" } \\
\text { ( } 2 \text { of } 3 \text { responses) }\end{array}$ & $\begin{array}{l}\text { - Frame 3: Digital lives and } \\
\text { "green Orwellianism” (1 of 3) }\end{array}$ \\
\hline
\end{tabular}

The broader city context can also be considered. Although a diversity of frames was evident at both workshops, some alternative frames were more prevalent at particular workshops. More participants in the Melbourne workshop emphasised significant current and emerging urban environmental risks due to climate change and proposed associated extreme adaptation measures (see Frame 4). This difference may be due to the more significant climate disruptions that have recently been experienced in Melbourne, in particular extreme heat events during the summer months. The Sydney workshop produced more glimpses related to reimagined suburban life. This may reflect a context in which concerns about urban sprawl had intensified — following the release of more land for housing on the fringe of the city-and associated additional attention was placed on "urban renewal” strategies for achieving more development within existing suburbs and increased density. Additionally, as car dependence and transport infrastructure provision are significant issues in both Melbourne and Sydney it was unsurprising to see this dimension of Frame 5 articulated in both workshops.

Relating the five frames to frames identified by other researchers, and to common framings of green transformations, suggests further insights. Knight [24] contrasts two framings of action to address climate change: Those framing it as a technological problem, and those who centrally see it as a problem 
generated by "the excesses of modern consumption". This cleavage is apparent in the contrast between Frame 2 and the more technology-centric frames. Scoones, Newell \& Leach $[25,26]$ argue that green transformations get framed in four different ways: Technocentric transformations; marketised transformations; state-led transformations; or as citizen-led transformations (e.g., transitioning to solidarity-based sharing or gift economies). They note that some frames focus on "the right combination of technologies" rather than "reorganizing economies or institutions and unsettling power relations" as per a technocentric transformation narrative [26]. The consistency of the research findings with the framings identified in other studies is, perhaps, indicative of deeper sets of competing beliefs and values. Indeed, Benford and Snow [11] argue that frames "function as innovative amplifications and extensions of, or antidotes to, existing ideologies or components of them”.

\subsubsection{Potential for Frame Conflict, Contests and/or Alignment}

Participant deliberation on the glimpses revealed the potential for both frame conflict and alignment processes. On the conflict side, contrasting preferences were articulated and some participants expressed concerns about how the wider community might respond to the concepts. For example, one participant remarked that “I think the output was great for us but I can't see it being engaging for an older citizen, [or] a member of the parliament etc.”. With respect to conflicting preferences, some participants were attracted to highly localised ways of life that are far more communal (as per some of the ways the "localised urban sustainability" frame was visualised), whereas others reacted strongly to the sense that communalisation and localisation was being presented as the "way to go". There were similar differences and tensions in participants' responses to "green Orwellianism”.

Building on Snow et al.'s [10] analysis of frame alignment processes, there may be opportunities for what they term frame bridging, frame amplification, frame extension, or frame transformation. For example, frame bridging refers to "the linkage of two or more ideologically congruent but structurally unconnected frames regarding a particular issue or problem” [10]. Frame bridging could be attempted by trying to link the more technocentric frames (e.g., "Low-carbon transitions through digital lives and "green Orwellianism" [Frame 3] and "Low-carbon transitions as changes to city-scale "hard" infrastructure and larger-scale systems” [Frame 5]), or to link the frames that more strongly emphasise social and/or cultural change (e.g., "localised urban sustainability" [Frame 1] and "radical shifts in political economy and material consumption” [Frame 2]). Additionally, frame extensions could be attempted by encompassing additional interests or points of view that are "of considerable salience to potential [frame] adherents" [10]. For example, those promoting a "localised urban sustainability" future could consider ways of portraying such urban futures which would be more congruent with potential adherents who have different values and interests (e.g., those with less collectivist social values) and that would also encompass additional auxiliary interests.

Sociological research has consistently demonstrated the importance of frame alignment and "micromobilisation" processes [10,11,13,27,28]. Effective frames are often those which have been crafted to "resonate with varying groups" and have a high degree of interpretive flexibility [13].

Linkages between frames evident in some data also indicate such opportunities. Some participants expressed more than one of the identified frames, for example both Frame 1 and 5 . The reason for this 
linkage requires more investigation; however it may be due to the synergies between urban redevelopment (Frame 1) and improved public and active transport systems (Frame 5).

However, some level of frame conflict may be unavoidable. For example, framing contests between those who see radical reorganisation of the structure of contemporary economies (e.g., towards post-growth economies) as an essential part of low-carbon transitions and resilience (as per Frame 2) and others who favour technocentric-style green transformations may be inevitable.

The overall diversity of frames also meant that there was a risk that adherents to the dominant frame would dominate discussion and prevent other framings from being heard, with framing contests resulting in some frames being marginalised. A diversity of frames also raises complications for visioning processes, an issue that we briefly take-up in the discussion section below.

\subsection{Discussion}

\subsubsection{Framing Processes and the Use of Visioning Processes in Sustainability Research}

Visioning practices are often centred on the pursuit of a shared vision or, at the very least, defining and agreeing on common goals and associated plans. As McCann notes, visioning is typically viewed and practiced as a consensus-oriented approach that, in urban contexts, "develops goals for the future of a city through consensus-based meetings open to all interested parties” [29]. This study, and related theorisation by sustainability-oriented scientists $[14,25,30]$, raises questions about the suitability of this approach for complex prospective changes such as urban low-carbon transitions and resilience-focused urban change. Political contention over alternatives and multiple proposed low-carbon transformations-rather than consensus - may be inevitable and in some cases more desirable [25].

Theorisation of frames and framing processes provides some support for this view. If, as Schon and Rein [12] have argued, the ways actors' cognitively process problematic complex situations (such as the challenge of decarbonising cities) is necessarily both selective and partial then exploration of multiple frames and associated contested pathways may be necessary to address such situations.

The approach taken in VP2040 was to question the common focus on defining a singular blueprint of the desired future-which is typically a single detailed vision —and to, instead, explore glimpses of possible futures. Whilst the process didn't explicitly explore or make space for multiple frames, the emphasis on glimpses (plural) — rather than a single blueprint-allowed for their expression.

Additional considerations emerging from this study relate to the question of how to address the existence of multiple frames and potential framing contests in visioning processes. This study shows that even fairly homogenous groups — such as the groups convened in the visioning processes discussed here-don't necessarily share a single problem frame or collective action frame. Diverse groups are likely to contain participants that adhere to a greater diversity of frames. The study suggests that organisers and facilitators of visioning exercises should be more attentive to framing processes and the potential for framing contests, as well as the ways these shape the outcomes of such exercises.

\subsubsection{Additional Reflections on the Design of the Visioning Process and Research}

Convenors of visioning processes also need to be mindful that the framing and design of such processes shapes the outputs and outcomes. A few features of the study are discussed below. 
The process had a dual focus on decarbonisation and resilience. This decision may have led to a stronger focus on food production (although this is also important for emissions reduction), urban greening (as per the ideas for mitigating the urban heat island effect), and localised resilience and self-reliance (as per Frame 1). This highlights the influence of process framing decisions.

This study also indicates that the convenors of visioning processes need to be mindful of how the institutional and life settings of participants can shape process outcomes. This is especially the case for workshops for which attendance is invitation only. For example, in the present study achieving a better balance of participants from local, State, and Federal government perhaps should have been a priority (although process convenors often have limited control over this). This may have reduced to dominance of a single frame-localised urban sustainability_and thereby encouraged fuller consideration of the highly complex problems being grappled with in the workshops.

The central roles played by the designers (some of whom are architects by profession) may also have influenced the process outcomes, including contributing to the "localised urban sustainability" frame being central to most glimpses. Their usual focus on smaller-scales (such as buildings, precincts, streetscapes, etc.), rather than whole cities and associated large-scale systems, may have influenced some of the visualisations/glimpses.

The potential influence of the designers' own preferences also cannot be entirely discounted. Some design teams/designers and participants had also previously worked with VEIL on similar projects. Linked with this, the research focus of the lab leading the VP2040 project (the Victoria Eco-Innovation Lab [VEIL]) on distributed systems, food security, and resilience may also have influenced the results of the study.

Additionally, we can consider the implications of using framing theory and examining framing processes. The key strengths include the following: it is a useful approach for surfacing and (thereby) discussing existing selective understandings of complex problem situations; framing attends to the meaning work done by actors as they engage with—and prescribe solutions to-complex social problems by constructing and using interpretive frames [11]; and the theory recognises cognitive limitations [12]. The positives must be balanced with the potential to reinforce differences and conflict (e.g., by highlighting the existence of competing frames) and participant considerations.

\section{Conclusions}

This study identified five framings of low-carbon resilient cities and found that diverse institutionally-related and culturally-grounded framings of issues are voiced, even when relatively homogenous groups participate. Consistent with Schon and Rein's conceptualisation of frames-as selective diagnostic-prescriptive stories based on underlying structures of beliefs, perceptions, and appreciation - the frames can be understood and contrasted according to the problem diagnosis and description (diagnostic framing) and associated prescriptions (prognostic framing). The identified frames varyingly have the potential to contribute to conflicts or actor alignment. The survey data, whilst having significant limitations, provided evidence of related framing processes.

As noted in the discussion that followed, the study also suggests that the convenors and facilitators of visioning processes need to be aware of framing processes and related dynamics (e.g., framing contests). Such processes and dynamics may have contributed to "localised urban sustainability” being 
the dominant frame in the workshops. At a minimum the organisers and facilitators of visioning exercises need to be attentive to framing contests and related social processes. A further key consideration is whether a visioning exercise seeks to open up a complex issue (such as by surfacing and clarifying frames) or to achieve agreement on a singular, i.e., consensual, agenda.

This study has made two related contributions. First, it demonstrated the diverse ways actors frame the problems of urban decarbonisation and resilience. The five frames would be a good starting point for other urban decarbonisation/resilience projects (with appropriate contextualisation). For example, it may be possible to use them as collective action frames for building coalitions. The diverse ways that actors frame such problems also means that if a sustainable city-related visioning process aims to achieve consensus the process will either: need to allow for framing contests (by welcoming or making room for them) and achieve a deeper level of frame reflection and associated reframing [12]; or it must involve participants from similar institutional and life settings (but those actors will necessarily have a selective and partial understanding of the problems being addressed). This has major implications for visioning practices. Second, it demonstrated the need to be aware of framing processes in the context of visioning and action for realising sustainable cities. As noted earlier, such action may be enhanced by the exploration of multiple frames and associated contested pathways such as through further examination of the frames identified in this paper and by enabling related collective action.

\section{Acknowledgments}

We would like to acknowledge funding received through the Cooperative Research Centre for Low-carbon Living and its partners that has supported this research (Visions and Pathways 2040 project).

\section{Author Contributions}

Stephen McGrail conceived of the paper, led the data analysis and wrote the first draft of the paper. A. Idil Gaziulusoy and Paul Twomey contributed to the survey design and research, data analysis, and reviewed the draft manuscript. All authors were co-facilitators of the visioning workshops reported on in this paper.

\section{Conflicts of Interest}

The authors declare no conflict of interest.

\section{References}

1. Bakker, S.; van Lente, H.; Meeus, M.T.H. Credible expectations-The US Department of Energy’s Hydrogen Program as enactor and selector of hydrogen technologies. Technol. Forecast. Soc. Change 2012, 79, 1059-1071.

2. Van Lente, H.; Rip, A. Expectations in technological developments: An example of prospective structures to be filled in by agency. In Getting New Technologies Together: Studies in Making Sociotechnical Order; Disco, C., van der Meulen, B., Eds.; Walter de Gruyter: Berlin, Germany, 1998; pp. 203-229. 
3. Van Lente, H. Navigating foresight in a sea of expectations: Lessons from the sociology of expectations. Technol. Anal. Strateg. Manag. 2012, 24, 769-782.

4. Borup, M.; Brown, N.; Konrad, K.; van Lente, H. The sociology of expectations in science and technology. Technol. Anal. Strateg. Manag. 2006, 18, 285-298.

5. Brown, N.; Rappert, B.; Webster, A. Contested Futures: A Sociology of Prospective Techno-Science; Ashgate Publishing Ltd.: Aldershot, UK, 2000.

6. Brown, N.; Rappert, B.; Webster, A.; Cabello, C.; Sanz-Menendez, L.; Merkx, F.; van de Meulen, B. Foresight as a Tool for the Management of Knowledge Flows and Innovation (FORMAKIN)_Final Report; European Commission: Brussels, Belgium, 2001.

7. Truffer, B.; Voß, J.-P.; Konrad, K. Mapping expectations for system transformations: Lessons from Sustainability Foresight in German utility sectors. Technol. Forecast. Soc. Change 2008, 75, 1360-1372.

8. Kaplan, S. Framing contests: Strategy making under uncertainty. Organ. Sci. 2008, 19, 729-752.

9. Moser, S.C.; Boykoff, M.T. Climate change and adaptation success: The scope of the challenge. In Successful Adaptation to Climate Change: Linking Science and Policy in a Rapidly Changing World; Moser, S.C., Boykoff, M.T., Eds.; Routledge: London, UK, 2013.

10. Snow, D.A.; Burke Rochford, E.; Worden, S.K.; Benford, R.D. Frame alignment processes, micromobilization, and movement participation. Am. Sociol. Rev. 1986, 51, 464-481.

11. Benford, R.D.; Snow, D.A. Framing processes and social movements: An overview and assessment. Annu. Rev. Sociol. 2000, 26, 611-639.

12. Schon, D.A.; Rein, M. Frame Reflection: Towards the Resolution of Intractable Policy Controversies; Basic Books: New York, NY, USA, 1994.

13. Fligstein, N.; McAdam, D. A Political-Cultural Approach to the Problem of Strategic Action, in Rethinking Power in Organizations, Institutions, and Markets; Courpasson, D., Golsorkhi, D., Sallaz, J.J., Eds.; Emerald Group Publishing Limited: Bingley, UK, 2012; pp. 287-316.

14. Leach, M.; Scoones, I.; Stirling, A. Dynamic Sustainabilities: Technology, Environment, Social Justice; Earthscan: London, UK; Washintgon, DC, USA, 2010

15. Vogel, K.M. Iraqi Winnebagos ${ }^{\mathrm{TM}}$ of death: Imagined and realized futures of US bioweapons threat assessments. Sci. Public Policy 2008, 35, 561-573.

16. Vogel, K.M. Framing biosecurity: An alternative to the biotech revolution model? Sci. Public Policy 2008, 35, 45-54.

17. Geels, F.W. Regime Resistance against low-carbon transitions: Introducing politics and power into the multi-level perspective. Theory C. Soc. 2014, 31, 21-40.

18. Turnheim, B.; Geels, F.W. Regime destabilisation as the flipside of energy transitions: Lessons from the history of the British coal industry (1913-1997). Energy Policy 2012, 50, 35-49.

19. Farla, J.C.M.; Markard, J.; Raven, R.; Coenen, L. Sustainability transitions in the making: A closer look at actors, strategies and resources. Technol. Forecast. Soc. Change 2012, 79, 991-998.

20. Wirth, L. Urbanism as a way of life. Am. J. Sociol. 1938, 44, 1-24.

21. Urry, J. Societies beyond Oil: Oil Dregs And Social Futures; Zed Books: London, UK; New York, NY, USA, 2013.

22. Dennis, K.; Urry, J. After the Car; Polity Press: Cambridge, UK, 2009.

23. Urry, J. Climate change, travel and complex futures. Br. J. Sociol. 2008, 59, 261-279. 
24. Knight, E. Reframe: How to Solve the World”s Trickiest Problems; Black, Inc.: Collingwood, Australia, 2012.

25. Scoones, I.; Newell, P.; Leach, M. The politics of green transformations. In The Politics of Green Transformations; Scoones, I., Leach, M., Newell, P., Eds.; Routledge: New York, NY, USA, 2015.

26. Scoones, I.; Leach, M.; Newell, P. The Politics of Green Transformations; Routledge: New York, NY, USA, 2015.

27. Fligstein, N.; McAdam, D. A Theory of Fields; Oxford University Press: New York, NY, USA, 2012.

28. Snow, D.A.; Benford, R.D. Ideology, frame resonance, and participant mobilization. Int. Soc. Mov. Res. 1988, 1, 197-218.

29. McCann, E.J. Collaborative visiong or urban planning as therapy? The politics of public-private policy making. Prof. Geogr. 2001, 53, 207-218.

30. Stirling, A. Transforming power: Social science and the politics of energy choices. Energy Res. Soc. Sci. 2014, 1, 83-95.

(C) 2015 by the authors; licensee MDPI, Basel, Switzerland. This article is an open access article distributed under the terms and conditions of the Creative Commons Attribution license (http://creativecommons.org/licenses/by/4.0/). 